\title{
Three essays on the profitability, risk, and viability of family firms in a developing economy
}

\author{
Kamol Khaemasunun \\ West Virginia University
}

Follow this and additional works at: https://researchrepository.wvu.edu/etd

\section{Recommended Citation}

Khaemasunun, Kamol, "Three essays on the profitability, risk, and viability of family firms in a developing economy" (2004). Graduate Theses, Dissertations, and Problem Reports. 2141.

https://researchrepository.wvu.edu/etd/2141

This Dissertation is protected by copyright and/or related rights. It has been brought to you by the The Research Repository @ WVU with permission from the rights-holder(s). You are free to use this Dissertation in any way that is permitted by the copyright and related rights legislation that applies to your use. For other uses you must obtain permission from the rights-holder(s) directly, unless additional rights are indicated by a Creative Commons license in the record and/ or on the work itself. This Dissertation has been accepted for inclusion in WVU Graduate Theses, Dissertations, and Problem Reports collection by an authorized administrator of The Research Repository @ WVU.

For more information, please contact researchrepository@mail.wvu.edu. 
Three Essays on the Profitability, Risk, and Viability of Family Firms in a Developing Economy

Kamol Khaemasunun

Dissertation submitted to the

College of Business and Economics

at West Virginia University

in partial fulfillment of the requirements

for the degree of

Doctor of Philosophy

in

Economics

Stratford M. Douglas, Ph.D., Chair

Ashok B. Abbott, Ph.D.

Ronald J. Balvers, Ph.D.

Santiago M. Pinto, Ph.D.

William N. Trumbull, Ph.D.

Division of Economics and Finance

Morgantown, West Virginia

2004

Key words: family business, profit, risk, and survival

(C) Copyright by Kamol Khaemasunun, 2004 


\section{Abstract \\ Three Essays on the Profitability, Risk, and Viability of Family Firms in a Developing Economy}

Kamol Khaemasunun

The objective of this dissertation is to examine the family firms in term of profit, risk and the probability of their survival in developing countries. The first chapter gives an introduction to this study. The second chapter provides an analysis of family businesses in regard to their performance, since there have been claims in the popular press that familycentered "crony capitalism" significantly contributed to the Asian financial crisis of 1997. Small, tightly focused firms can, however, be well managed by family hierarchies. As firms grow and diversify, family management is often displaced by diffuse ownership and independent managers. Between these two extremes, a firm run by two or three families may find its assets subject to expropriation as a commons. The second chapter provides empirical support for this story of development, with an analysis of a data set from Thailand, where regulations facilitate accurate identification of family influence on boards of directors. Regression results show the single-family managed firms and "corporate"-style firms (in which directors are not related) have significantly higher Tobin's q than "family-partnership" managed firms (in which a small number of different families dominate the Board), and higher Tobin's q is associated in the data set with higher firm performance, by a variety of measures. Thus, family partnerships, not family firms, may create problems for emerging economies.

In chapter three, the study uses total return variance, the CAPM, and the Fama French three-factor model to identify whether the different styles of management are associated with different degrees of risk. According to the total return criterion, family firms are riskier than 
the other two styles of management. Results from the CAPM model regressing on Thai stock market returns suggest that Thai family firms are riskier than corporation firms. Using the CAPM model regressing on world market returns, Thai family firms, partnerships, and corporate-style firms appear to be equally risky. Abnormal returns are positive in all cases, but not significantly different from each other. The average abnormal returns from the Fama-French model are also lower (lower absolute pricing errors) than that from the CAPM. The Fama French model fits the data better than the CAPM, and provides different results when using Thai vs. US factors. Thai family firms are riskier in the Thai data but the corporate-style firms are riskier in US data. However the Fama-French model implies far smaller abnormal returns and thus appears to explain the risk and return relationship better than the CAPM. Results from the Fama-French model indicate that Thai family firms are riskier (and have higher returns) because they are smaller in size, and tend to be value firms since they have high loadings on the book-to-market-value factor.

In chapter four, empirical results suggest that family companies and partnership companies have a lower likelihood of filing for bankruptcy than corporate-style firms do. They also suggest that having a failed banker on the board of directors increases the chance of a firm being delisted, since having a failed banker on a firm's board decreases its chances of getting new loans. In chapter five, I summarize the main conclusions of the dissertation and discuss future research. 


\section{Acknowledgements}

First, I am indebted to my advisor, Prof. Stratford Douglas for his guidance and inestimable support throughout this study. I have learned a lot of techniques from his expertise in doing research. I thank Prof. Balvers and Prof. Abbott for providing me with many useful comments, as well as suggestions. I also would like to thank Prof. Subhayu, Prof. Pinto, and Prof. Trumbull for their assistance and their advice on my research. The standard disclaimer applies. 


\section{Dedication}

To my dad and mom who unconditionally love me with all their heart. To my brother and my sisters who support and encourage me all the way. 


\section{Table of Contents}

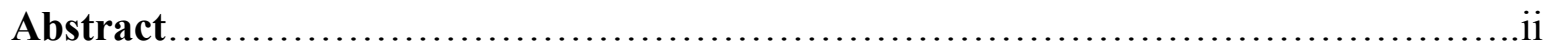

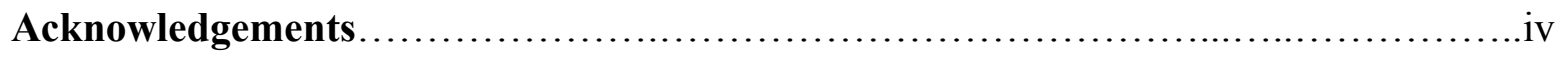

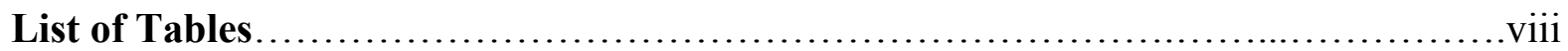

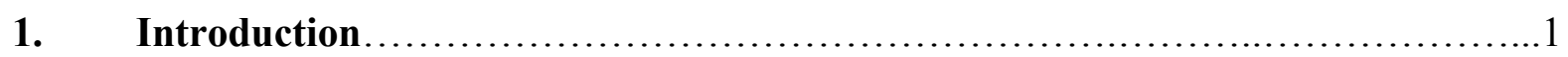

2. Do Family Businesses Perform as Poorly as is Claimed? Evidence from

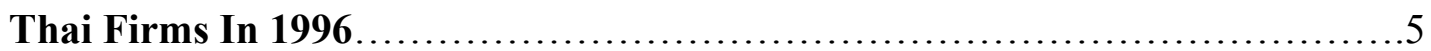

2.1. Introduction...........................................................

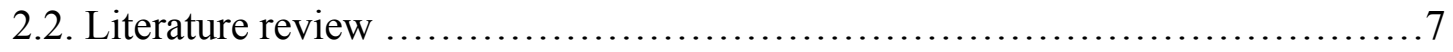

2.2.1 Evaluation of Family Business Performance ...........................8

2.2.2 Firm Performance and Ownership Concentration.......................10

2.2.3 The Relationship Between Tobin's q and Performance...................12

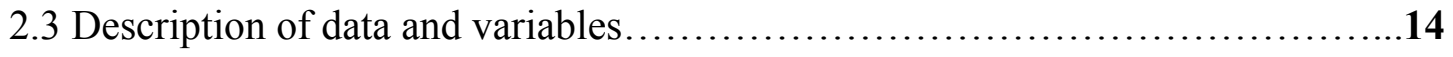

2.3.1 Description of data................................................. 14

2.3.2 Description of variables......................................... 15

2.3.2.1 Dependent variables ...................................... 15

2.3.2.2 Explanatory variables .................................... 16

2.3.2.3 Control variables ............................................18

2.4 Econometric Model and Empirical results.................................. 18

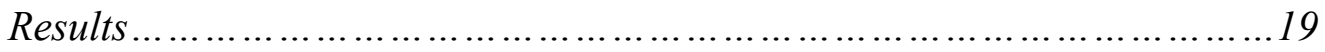

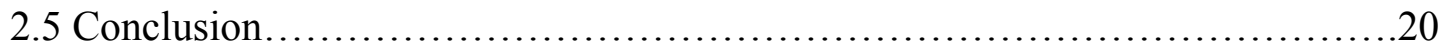


3. Are Family Firms Riskier or Not? If So, Do They Provide Higher Returns?....22

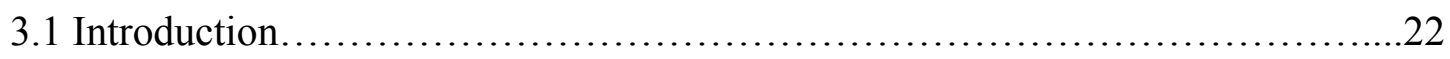

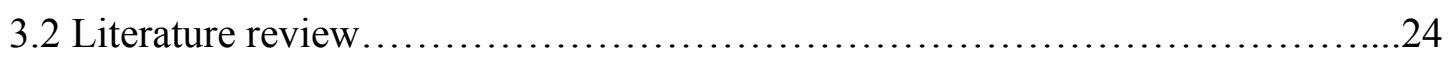

3.2.1 The concept of Beta …....................................................24

3.2.1.1 Estimation Methodology on CAPM..............................26

3.2.2 Fama French Three-Factor Model ......................................28

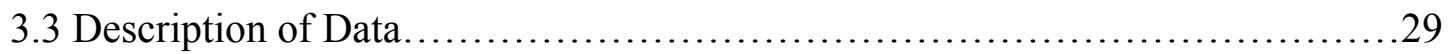

3.4 Empirical results........................................................ 30

3.4.1 Results from analysis of the risk and return base on mean and

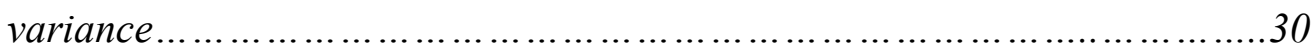

3.4.1.1 Total risk comparison ...............................................

3.4.2 Systematic risk from CAPM and Abnormal return ...................32

3.4.2.1 Unleverage beta comparison ................................32

3.4.2.2 Abnormal return from CAPM...........................33

3.4.3 The Fama French Model..................................................

3.4.3.1 Fama French Three factor as a measure of Risk with

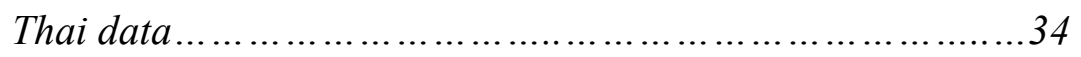

3.4.3.2 Fama French Three factor as a measure of Risk with

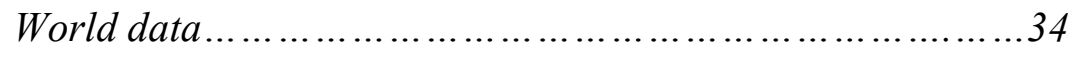

3.4.3.3 Abnormal return for Fama French model .................35

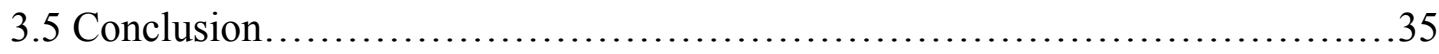

4. Do family firms survive financial crisis better?................................37

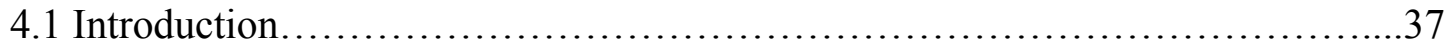


4.2 Literature review.

4.2.1 Financial market and bankruptcy process in Thailand....................39

4.2.2 Does Probability of survival depend on style of management...........42

4.2.3 Bank-firm relationship benefit or threat .............................4 42

4.3 Description of data and variables......................................43

4.3.1 Description of data..................................................43

4.3.2 Description of variables...........................................44

4.3.2.1 Dependent variables........................................44

4.3.2.2 Explanatory variables..................................45

4.3.2.3 Control variables .........................................4 47

4.4 Econometric Model and Empirical results...............................48

Results.......................................................51

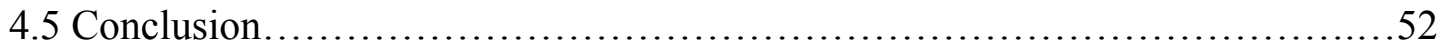

5. Summary, Conclusions and Directions of Future Research..........................54

5.1 Summary and conclusions of the dissertation............................54

5.2. Directions of future research....................................... 56

References..................................................................................57

Appendix I: Law of person's identification..............................................72

Appendix II: Regressions that use Herfindahl-Hirschman index (HHI).................74 


\section{List of Tables}

Table 2.1: Sample Descriptive......................................................60

2.1.1A: Industrial composition and characteristics of companies listed in the sample

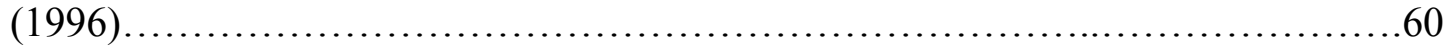

2.1.1B: Descriptive information of 315 listed companies in the sample..............61

2.1.1C: Number of firms by style of management in five industry sectors...........61

Table 2.2 Descriptive information of firms by styles of management.....................62

Table 2.2A Hypothesis Testing to Detect a Statistical Difference Among the True Proportion Means from Three Different styles of management.............................62

Table 2.3 Descriptive information of firms by industry sectors: Agriculture, Commerce, Construction, Manufacturing, and Service sectors....................................63

Table 2.4 Coefficient estimates from regressions of Tobin's Q on the management style

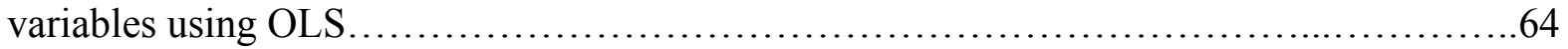

Table 2.5 Coefficient estimates from regressions of performances on the Tobin's Q variables

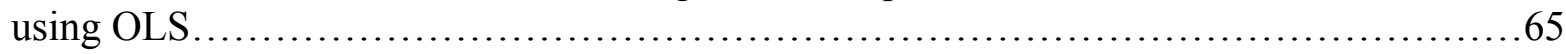

Table 2.6 Coefficient estimates from regressions of Tobin's q on the family director variables and Tobin's q on performance variables using 2 SLS.

Table 3.1 Mean and Variance of Returns by Three Different Styles of Management

Table 3.2 Descriptive Statistics Comparison of Unleverage Beta from Three Different Styles of Management Use Excess Return Calculated from Index the Stock Exchange of Thailand and World Market Index as Market Return.

Table 3.3 Abnormal Returns from Three Different Styles of Management Using CAPM with Thai Market Return and World Market Return.

Table 3.4 Three-factor Fama and French Regressions that Use Book-to-Market, Size SmallBig Returns, Value-Growth Returns, and Monthly Excess Returns on the Thai Market Portfolio and U.S. Market Portfolio to Explain Monthly Excess Returns on Three Different

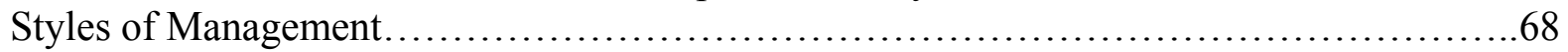

Table 4.1 Descriptive variables use in Binomial and Bivariate Probit......................69

Table 4.2 Regressions that use binomial probit model to explain bankruptcy and liquidation

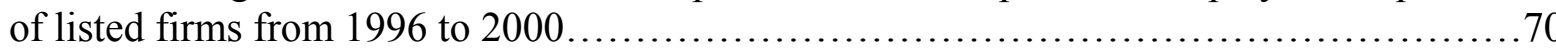


Table 4.3 Regressions that use bivariate probit model to explain bankruptcy and liquidation

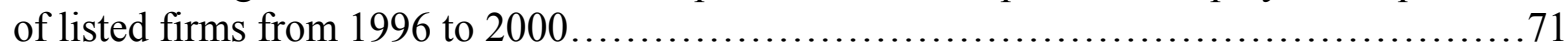




\section{Chapter 1}

\subsection{Introduction}

Failures in East Asian corporate governance have recently received wide attention, as well as some of the blame for the East Asian Financial Crisis of 1997. Faccio, Lang, and Young (2001) showed that family-based management and ownership is common in the region and has become a major focus of analyses of the crisis. Most of the literature uses the shareholders' concentration as a measure of whether or not a firm is a family business. There are serious problems with this measure, however. The shareholders of a firm who are not involved in management should have nothing to do with the firm's performance, risk, or its survival. The contribution of this dissertation is to develop a new measure of family control of a firm, and to use it to explore the effect of family control on the firm's performance, risk and probability of survival.

In most countries, it is difficult to distinguish family-run companies from other types of management structures using publicly available data. Thailand presents a unique case that is especially well adapted to addressing the effect of family ownership and control. Thai law is strict in requiring that only family members can share last names (appendix 1), which allows us to identify family-run firms with some precision.

Businesses in Thailand, as in most other countries, often begin with certain skills and expertise within a single family. As the business expands and seeks new capital, it may get listed on the Stock Exchange of Thailand. After the first generation, sons-in-law are taken in as part of the family. In this process, additional last names are added to the firm's

directorship, creating what I refer to here as a "family partnership" firm. As firms grow and diversify these structures eventually take on a more modern, corporate style of management. 
In this dissertation, I explore the unique features of Thai data to investigate the effect of family control and interlocking directorates on the profitability, risk, and viability of family firms in Thailand during the East Asian financial crisis of 1997.

First, I study the directorship of listed companies from the stock exchange of Thailand in 1996 to see whether family companies are associated with poor investment and performance, using a variety of performance indicators. To measure company performance, I use information from financial statements and from the I-SIMS database produced by the Stock Exchange of Thailand. The variables are gross profit margin, return on assets, return on equity, and excess stock return. In the first essay, my data analysis supports the pattern of transformation described by Alfred Chandler (1977). From the directors' last names I classify each as a "family firm," (in which only one family has multiple directors) a "partnership" (in which two or three families have multiple directors) or a "corporation" (in which no directors are related). For some purposes, following the literature I group together the family and partnership firms into one category, called a "crony" firm. While I find that "crony" firms so defined perform worse than "family firms" and "corporations," my evidence strongly suggests that grouping family and partnership firms together is misleading. In fact, there is no significant difference between family and "corporate" firms, and both perform significantly better than partnerships.

Second, I attempt to measure the risk of investing in the family style of management, compared to partnership and corporate styles of management. I use the total return variance, the CAPM beta, and the Fama-French three-factor model to identify whether the different styles of management are associated with different degrees of risk. The family firms turn out to be riskier than the other two styles of management, by all measures. 
Using the CAPM, I find that the average unleveraged betas for family firms are significantly higher than the corporate-style firms when the return of the Thai market index is used as a proxy for the market return in the CAPM regression. After analyzing different degrees of risk, I calculate the abnormal return of each firm. The results show that the abnormal returns are positive for all three management styles, but that the styles are not significantly different from each other. The problem with using the CAPM is that the average abnormal returns are as high as the average return from the estimation periods. Average absolute pricing errors (intercept or alpha CAPM) of the CAPM are three to four times those of the three-factor model in the Thai market.

The average abnormal returns calculated from the Fama-French model are lower (lower absolute pricing errors) than those calculated using the CAPM, and the Fama-French model provides a better fit. This model provides significantly different results when using Thai and U.S. factors. The family firms are riskier in the Thai data but the corporate-style firms are riskier in the U.S. data. My Fama-French results indicate that family firms are riskier (and have higher returns) because they are smaller in size and tend to be value firms since they have high loadings on the size and book-to-market-value factors.

Third, after the Asian financial crisis many financial intermediaries and listed firms were liquidated. I attempt to find out what determines which firms survived the crisis. In particular, I address the question whether family firms survive the financial crisis better than the other styles of management. My second concern in the third essay is with the bank-firm relationship. The financial system in Thailand relies mainly on financial intermediaries, including both financial companies and banks. Therefore, I examine whether the bank-firm relationship is a benefit or a threat to a firm. In the third essay, my findings suggest that 
companies whose boards of directors were dominated by one or two families were less likely to file for bankruptcy during the East Asian crisis than companies with a more dispersed directorship. I also find that family firms with interlocking directorates with banks were more likely to survive the crisis by reorganizing in a manner similar to filing Chapter 11 under U.S. bankruptcy law. However, creditors are more likely to force a firm to file for liquidation if the creditor's rights are strong and the creditors can recover their losses. 


\section{Chapter 2}

\subsection{Introduction}

Failures in East Asian corporate governance have recently received wide attention, even taking some of the blame for the East Asian Financial Crisis of 1997. Faccio, Lang, and Young (2001) showed that family-based management and ownership is common in the region and has become a major focus of analyses of the crisis. Within the region, however, many family firms have great prestige and have achieved remarkable success. My findings suggest that a blanket condemnation of family ownership is overly simplistic; as in other regions and times, single-family control provides an appropriate and productive control structure for smaller and newer East Asian firms.

In most countries, it is difficult to distinguish family-run companies from other types of management structures using publicly available data. Thailand presents a unique case that is especially well adapted to addressing the effect of family ownership and control. Thai law is strict in requiring that last names can only be shared by family members (appendix 1), which allows for the precise identification of family-run firms. Therefore, this paper studies the directorship of listed companies from the stock exchange of Thailand in 1996 and sees whether family companies are associated with poor investment and performance, using a variety of performance indicators.

Firm ownership and control often follows a pattern, or life cycle of firms, as the firm expands. The literature on corporate management (e.g., Alfred Chandler (1977)) suggests that small, tightly focused firms can be well managed by traditional single-family hierarchies. However, as firms grow and diversify, this structure becomes increasingly inadequate, and eventually firms adopt the more modern, corporate "m-form" style of governance. 
Businesses in Thailand, as in most other countries, often begin with certain skills and expertise within a single family. As the business expands and seeks new capital, it may become listed on the Stock Exchange of Thailand. After the first generation passes on, sonsin-law are taken in as part of the family. In this process, additional last names are added to the firm's directorship, creating what we refer to here as a "family partnership" firm. These family partnership firms are not as well adapted as either the well-focused family firms or the larger corporate m-form firms.

With diversity of family ownership, the firm's assets may take on the characteristics of a commons. As with the classic "tragedy of the commons," each family may be unable to stop the other families from appropriating assets, and therefore each family has a strong incentive to appropriate those assets for itself. If the firm survives the partnership stage, it may evolve into a full-fledged modern corporation with full separation between ownership and control. Thus, it is not family firms per se, but transitional family partnership firms that may create problems for emerging economies.

Our data and analysis in this paper support this pattern of transformation. From the directors' last names we classify each as a "family firm," a "partnership," or a "corporation" (in which no directors are related). As opposed to the corporate form, following the literature we define a "crony" firm as either a family-run or a partnership firm. While we find that "crony" firms so defined perform worse than "family firms" and "corporations", our evidence strongly suggests that grouping family and partnership firms together is misleading. In fact, there is no significant difference between family and "corporate" firms, and both perform significantly better than partnerships. 
In the next section, I have reviewed some literature about family businesses and their performance. In section 3, I have described data used in the study. In section 4, I have discussed the empirical results. Section 5 concludes my study.

\subsection{Literature review}

Akira Suehiro (1993) defined the family business as "a form of enterprise in which both the ownership and management are controlled by a family kinship group, either nuclear or extended, and the fruits of which remain inside that group, being distributed in some way among its members." In the broadest sense of the term, a business formed through an affiliation such as a family, a personal relationship, or a common place of origin may be defined as a family business. Later on, we will see that this broad definition of a family business may not be the best way to classify firms according to performance.

Faccio, Lang, and Young (2001) present evidence that Asian corporate governance problems are more severe than some commentators have suggested. Using low dividend payments as an indicator, they assert that owner-manager firms expropriated benefits from listed companies in East Asia. Lower dividend payments may be a sign of poor performance, but it is not the only explanation for low dividend payments, so it is important to assess a variety of performance indicators before drawing conclusions.

Family members hold the majority of the stock of a family business, and directors are often chosen from among the family members as well. In contrast, a typical publicly held corporation generally has a large number and variety of shareholders who are distinct from the firm's managers. Shleifer and Vishny (1997) argue that a good corporate governance system should combine some large investors with legal protection of both their rights and 
those of small investors. Fama and Jensen (1983) suggest that decision-making and control can be usefully combined in a proprietorship, small partnership, or closed corporation.

In many developing economies, the majority of businesses begin as family businesses. Claessens, Djankov, and Lang (2000) showed that two thirds of East Asian corporations are family businesses, in the sense that a single family holds a major share of the firm. Although Shleifer and Vishny (1997) may question East Asian family firm governance, the entrepreneur in a developing economy may have little choice but to enter the capital market as a family business. They believe that successful corporate governance systems, such as those in the United States, Germany, and Japan, combine significant legal protection of at least some investors with an important role for large investors. This combination provides extremely limited legal protection of investors in most other countries that have many family and insider-dominated firms.

Vishny et al, (1998) find that concentration of ownership of shares is negatively related to investor protection, and conclude that law enforcement differs a great deal around the world. Law enforcement is strong in common-law countries and it is weakest in the French-civil-law countries like Thailand. By going public, the family firm may be able to acquire the capital it needs to expand efficiently. From a social welfare point of view, expanded ownership opportunities afforded by public capital markets may reduce the inequality of income distribution. Liquidity and predictability in capital markets improve as the judicial system and accounting standards evolve and improve in developing economies.

\subsubsection{Evaluation of Family Business Performance}

Two approaches dominate the literature on evaluation of family businesses. First, the business science approach, including the business history literature, discusses the issue from 
the standpoint of corporate control. Second, the sociological approach attempts to understand business management from the aspects of social relationships and family structure.

The business science approach was developed by American scholars to study business transformation through time. Alfred Chandler (1977) argued that a firm is forced to change its management style when it expands its scale sufficiently. Thus, an independent management eventually takes over a successful family business. Useem (1984), a supporter of Chandler's theory, describes the developmental stages of U.S. capitalism using his concept of "the inner circle." Useem divides the history of capitalism into three distinct stages. First, family capitalism is based on an "upper class" principle. The second stage of management capitalism is based on the "corporate" principle. Third, Institutional Capitalism is based on a “class-wide" principle.

The sociological approach, in contrast, focuses on the social relationships of owners and managers of family businesses. One type of family firm keeps all of its business within the family. The "chaebol" in Korea is a good example of this category. The second type of family business includes a wide range of relationships in the broader sense. The "keiretsu" in Japan, as well as Chinese-run business groups in Taiwan and South East Asian countries such as Thailand, are examples of "affiliation networks."

These two approaches provide a framework for analysis of management in Thai companies. A single-family company may not be at great risk for expropriation, but an "affiliation network" or "partnerships" of families may be a better target for the abuses of crony capitalism. Owners can expropriate benefits by transferring high costs or debts from their own accounts to that of the listed company. This paper examines whether it is accurate 
to lump single-family firms and family-partnership firms together as "crony capitalist" firms, or whether the pejorative "crony" label should apply only to the partnerships.

\subsubsection{Firm Performance and Ownership Concentration}

Many analyses of corporate governance systems focus on legal protection of investors and on ownership concentration in corporate governance systems around the world. For example, Shleifer and Vishny (1997) conclude that high outside-ownership concentration is associated with high performance, because outsider owners with a large stake in the firm will monitor and change management whenever necessary. With lower concentration of outside ownership, poor performance is more likely due to expropriation.

Todd Mitton (2002) also argues that firms with higher ownership concentration tend to perform better. Indeed, firms with higher disclosure quality (such as having ADRs and auditors from "Big Six" accounting firms) generally performed better during the Asian Financial Crisis of 1997. Mitton believes that the benefit of concentrated ownership does not extend to concentrated ownership by managers. Similarly, Yurtoglu (2000) uses data from the Istanbul Stock Exchange to describe the characteristics of ownership structure of listed Turkish companies. He found that lower outside ownership concentration and pyramidal ownership structure have a negative effect on performance, as measured by return on assets, market to book ratio, and dividend payments.

Wiwattanakantang (2001a) investigated the effects of controlling shareholders on corporate performance using data from the Stock Exchange of Thailand in 1996. Her work confirms the same result that the firms with a high concentration of non-management shareholders have higher performance as measured by return on asset and sales to asset ratio. However, if the controlling shareholders are also managers then the performance of the firm 
tends to suffer, suggesting that expropriation might occur in firms that are owned and managed by the same family. However, she showed that family-controlled firms displayed significantly higher performance than the non-family firms. Similarly, Anderson and Reeb (2003) find that family firms perform better than non-family firms when a family member serves as CEO.

The regression models in these articles are similar in their choice of control and explanatory variables. The explanatory variable is the ownership concentration by outsiders, while the control variables are firm size, leverage, and industry dummy variables. Measurement of ownership concentration by outsiders is tedious and inaccurate, largely because it is often difficult to determine who owns the firm. Much of the stock may be owned by firms, which in turn are owned by individuals and other firms. Moreover, ownership can sometimes change hands rapidly.

The shareholders of the listed firms are irrelevant to firm performance if they are not involved in management of the firm. A family may also participate in the capital market as a major shareholder while professional management runs the business. As Lim (2000) shows, the Korean chaebol is owned and operated by the family, whereas Japanese keiretsu is owned by the group's member companies and run by the professional manager. The Japanese keiretsu allows professional management to maximize shareholder wealth. In Thailand, many firms with concentrated shareholding, such as the Siam Cement Group, are managed by professional managers. The major shareholder of the Siam Cement Group is the Crown Property Bureau. There are more than ten listed firms in the group, including the Siam Cement Public Company Limited, the Siam Pulp and Paper Public Company Limited, and 
Siam Tyre Public Company Limited. All are run by professional managers. These firms are among the best performing firms in the stock exchange of Thailand.

On the other hand, a Board of Directors is easy to identify, controls the firm, and generally holds office at least one year before changes occur. Therefore, unlike previous studies, I use the family structure of the Board membership to identify family firms. The significance of the composition of the Board of Directors is widely recognized in the literature. For example, Fama and Jensen (1983), and Klein (1998) support the idea that the presence of inside directors provides valuable information to Boards about the firms' longterm investment decisions.

East Asian firms are much different from most American cases. First, the principalagent problem in the form described by Jensen and Meckling (1976) is not important in East Asia because owners and managers are often the same people (Faccio, Lang, and Young 2001). Second, ownership concentration in East Asian firms is generally in the hands of owner-managers instead of outsiders. Large shareholders are generally able to put family members on the board of directors. Although small shareholders have the right to vote on important matters such as selecting the Board of Directors, in most cases they do not have enough power to select outsiders as directors. The Security Exchange Commission of Thailand requires all listed firms to have at least two outsiders on the Board, but the Board is allowed to appoint those "outsiders."

\subsubsection{The Relationship Between Tobin's q and Performance}

Tobin's q is traditionally defined as the ratio of the market value of the firm's installed capital to its replacement cost. The denominator, replacement cost, is the value of the physical capital if it were purchased today. A manager can raise the market value of the 
firm by investing in new projects that will generate excess profits in the near future. By the traditional q theory, then, a high value of q indicates that investors recognize extraordinary talents or opportunities of present management.

On the other hand, the "financial q" theory assumes perfect substitutability between new and existing capital. According to this line of reasoning, if Tobin's q is greater than one then the stock is overvalued. By the arbitrage theory of investment, the investor should invest in companies having $\mathrm{q}$ less than 1 , since it is undervalued. This means market price is lower than the book value. Palley (2001) explored these contradictory views of the traditional q and financial q. The book-to-market equity is used in most finance literature, which is the inverse of Tobin's q. Referring to Palley (2001), Fama and French (1996) show that size and market-to-book equity capture much of cross-section of the average stock returns. They explain that, on the one hand, weak firms with persistently low earnings tend to be high-book-to-market "value" firms with positive slopes on HML (relatively distressed), and higher future average returns; while on the other hand, strong firms with persistently high earnings are low-book-to-market "growth" firm with negative slopes on HML and low future average returns. Palley concludes that the relation between $\mathrm{q}$ and investment is an empirical issue. I have applied the book-to-market equity concept in measuring the risk of the family firm in chapter 3 .

The purpose of the present study is to examine whether there is a relationship between the roles of different styles of management and performance of the firm. In fact, as reported below, I find that the family structure of the Board has a significant impact on Tobin's q. Interpretation of this result in terms of firm performance depends crucially on whether the traditional or financial interpretation of Tobin's q applies in this case. Therefore, 
I also investigate the relationship between Tobin's q and firm performance, and I find evidence in support of the traditional interpretation of Tobin's q.

\subsection{Description of data and variables}

\subsubsection{Description of data}

The analysis in the following sections is based on publicly traded non-financial companies in Thailand in 1996. Bank, financial and insurance companies are excluded from the sample since it is difficult to measure their Tobin's q. In addition, the government regulates these sectors, which may affect their performances. The stock price, number of shares outstanding, and financial statements were collected from the I-SIMS database produced by the Stock Exchange of Thailand. The first and last names of the board of directors were manually collected from Manager Information Services (1996). There were 346 listed companies at the end of the year 1996. All firms were included in the sample if they met two criteria. First, the company must have been listed before 1996, which provides necessary data for the study. Second, the first and last names of the board of directors must have been listed in the Manager Information Service. Application of these two criteria reduced the sample size by approximately $10 \%$, to 315 companies.

Table 2.1 shows the industrial composition and characteristics of these 315 companies listed in the Stock Exchange of Thailand in 1996. Firms in the sample vary widely in terms of assets, book value of equity, leverage ratio, total revenue, Tobin's q, and the performance variables. Table $2.1 .1 \mathrm{C}$ indicates that firms spread fairly evenly across different management styles and industry sectors. 


\subsubsection{Description of variables}

\subsubsection{Dependent variables}

Although Tobin's q is defined as the ratio of stock market value of the corporation to the replacement cost of its physical capital, it is not easy to accurately determine the amount of physical capital from the financial statement. Standard accounting procedures are questionable, especially in the Thai case. As in most empirical studies, I measure Tobin's $q$ as the market value of equity, divided by the book value of the firm's assets.

To measure company performance, I use information from financial statements and from the I-SIMS database produced by the Stock Exchange of Thailand. The variables are gross profit margin, return on assets, return on equity, and excess stock return. Each of the performance measurements offers a different perspective as follows:

Gross profit margin is the firm's revenue minus cost of goods sold divided by revenue. Controlling for industry and capital structure, profit margins should be similar. Firms with low gross profit margins may be transferring profit to family-owned subsidiaries by selling them their products more cheaply, or paying them inflated prices for raw materials. Alternatively, management of these firms may not be able to control the cost of goods sold.

Return on assets (ROA) measures whether the listed companies are using their assets productively. If the company owns unproductive assets, its return on assets will suffer. This might indicate expropriation if the management has acquired assets that serve the family or management, but not the company. For example, family directors might buy real estate using a loan from the bank in the company's name, and use it for unrelated family business or pleasure. There was a favorable climate for this type of expropriation in Thailand before 
the Financial Crisis, because real estate property markets in Thailand were highly volatile and accounting standards were poor.

Return on equity (ROE) is the ratio of net income to firm equity. It measures how effectively the company makes profit relative to firm equity. It is a volatile measure though, because the proportion of equity in the firm's capital structure is highly variable, and is often quite small. Due to such problems, the ROE is notoriously difficult to explain using regression methods.

Excess stock return provides market information that may not be easily manipulated by the management of the firm. It is another way of measuring firm performance from the perspective of outsiders. Unlike the other measures, it is not dependent on accounting standards. Most financial economists prefer to use excess stock return, rather than accounting measures, to measure the performance of a firm.

\subsubsection{Explanatory variables}

Data from Thailand offer a unique advantage for this study, since, by law Thai, last names can be uniquely identified to members of a single family (appendix 1). In the past, many Chinese people migrated to Thailand. Many of them had the same last name or even the same first and last name without knowing each other, which caused confusion. To solve this problem, Thai law allowed each family to register a new unique Thai last name. Thai last names are lengthy for this reason, but it is easy to identify family directors by their last name.

For this study, I have classified companies into three categories: Family, Partnership, and Corporation, using data about the last names of directors. Family firms are defined as those whose board of directors has only one family with more than one member on the Board 
of Directors. If a firm's Board of Directors has two or more families with more than one Board member, then it is a partnership firm. If a firm's Board of Directors has no families with multiple members on the Board, it is termed a corporation. To test whether family influence in general affects a firm's performance, I have created another category for one set of regressions I create another category, the crony capitalist firm, which consists of all family firms and partnerships.

Cronyism is a kind of extended family oriented culture. In Asian countries, family expansion is normal, especially among wealthy families. The "cronies" stick together to pursue benefits from family business as described by Suehiro (1993). The founder of the firm may be a talented businessman who leads the whole family to fame and fortune. He keeps the firm alive and prosperous, and provides a fair share to each family member who contributes to the firm. As the firm grows, another family or families may join the firm, creating a partnership firm. Regression results reported below indicate that the partnership form, and not the single-family form, may be solely responsible for the poor reputation of family firms.

Table 2.2 describes the characteristics of the four management style categories. Family firms have the smallest average size, and they have the highest debt to equity ratio. The average debt ratios of both family and partnership firms are high, while the corporation average debt ratio is relatively low. The classification of three styles of management is tested by the one-way ANOVA. The proportion variable is defined as the number of directors with the same last name divided by the total number of directors. The results in table $2.2 \mathrm{~A}$ show that there is a strong evidence of a difference among proportions among these three different styles of management. 


\subsubsection{Control variables}

The Stock Exchange of Thailand defines 31 categories of industries, which I have combined into five industry sectors. The agriculture sector consists of agriculture, food and beverage. The commerce sector consists of commerce, packaging, pharmaceutical products, and cosmetic industry categories. The construction industry sector consists of the building materials, household goods, and property development industries. The manufacturing sector consists of chemicals and plastics, electrical products and computers, electrical components, jewelry and ornaments, machinery and equipment, mining, printing and publishing, pulp and paper, textiles, and vehicles and parts industries. The service sector consists of communications, energy, entertainment and recreation, health care services, hotel and travel services, professional services, and transportation.

The size variable is measured by the natural logarithm of total revenue of the firm.

Some articles also use total assets or market value as a measure of size. From our descriptive data, the average size of listed firms within each sector, ranked from smallest to the largest as measured by total assets, are agriculture, commerce, manufacturing, construction, and service. Leverage is measured as the book value of the total debt divided by the book value of equity. It is lowest in the service sector and highest in the construction sector.

\subsection{Econometric Model and Empirical results}

For each of the performance measures I have estimated two structural equations, with Tobin's Q and firm performance as the dependent variables.

$$
\begin{aligned}
& \text { Tobin's q }=\alpha_{1}+\gamma_{1}(\text { control variables })+\beta_{1}(\text { Style dummies })+\varepsilon_{1} \\
& \text { Performance }=\alpha_{2}+\gamma_{2}(\text { control variables })+\beta_{2}(\text { Tobin's } q)+\varepsilon_{2}
\end{aligned}
$$


The style dummies are dummy variables indicating the family structure of the Board of Directors (i.e., family, corporation, partnership, and crony, as defined above). The control variables for the Tobin's Q model are firm size, leverage, and industry dummies. I have excluded leverage and the style dummies from the performance equation.

This is a triangular simultaneous equations model, and the endogeneity of Tobin's q is therefore of potential concern. In a triangular model, two-stage least squares (2SLS) from table 6 is consistent, but ordinary least squares (OLS) will be consistent and more efficient if the model is fully recursive, i.e., if the errors in the two structural equations are independent. I have reported both OLS and 2SLS results and done a Wu-Hausman test to check whether 2SLS is necessary or not. These tests support the use of OLS for all specifications except for ROE. Secondly, I have tested the over-identification restrictions for the performance equations. I have found that excluding family directorship structure from the performance equation is supported by the test for all performance variables except ROE.

\section{Results}

Table 2.4 presents the regression results of Tobin's q on the different types of company management. The first column appears to indicate that the "crony" structure (i.e., either family firm or family partnership firms) has a negative and significant effect on Tobin's q. The regression in the second column shows that the first regression is misleading, however; both the family and corporate coefficients are positive and significant, indicating that both types of firms have significantly higher levels of Tobin's q than will be found in partnerships. In addition, an F test shows no statistically significant difference between the family and corporate firms $\left(F_{1,306}=1.93, p=.17\right)$. Thus, the empirical results suggest that 
the low levels of Tobin's q associated with "cronies" may in fact be solely the result of failures of the family partnership form.

Table 2.5 shows results of regressing the various performance measures on Tobin's $\mathrm{q}$ and control variables, using OLS. The results indicate that Tobin's $q$ is positively related to performance. Thus, family firms and corporations, which generally have higher levels of Tobin's q, can be expected to perform better than partnerships.

I have also created three variables, HHI, HHIA, HHIB, to measure the concentration of the board of directors. The Herfindahl-Hirschman index (HHI) is a well-known concentration measure. HHIA is a dummy variable indicating an HHI higher than 1000, and HHIB indicates an HHI greater than 1800. The HHI coefficients, however, are insignificant with Tobin's q and the firm performance dependent variables (see appendix table 2.4a, 2.5a, $2.5 \mathrm{~b}, 2.5 \mathrm{c})$.

\subsection{Conclusion}

Family firms are smaller and more leveraged than other firms. To be able to borrow more money, a family firm must have prospects for future income that convince financial institutions to lend them more money. These income prospects are reflected in Tobin's q, and a higher Tobin's q is associated with better firm performance, as measured by a variety of accounting measures and market returns. Regression results, in this paper, clearly indicate that family and corporate-style firms have significantly higher Tobin's q than family partnership firms.

A low Tobin's q indicates lower prospects for future profits, and lower levels of q are associated with family partnerships. This empirical result is consistent with our model of the 
family partnership type of firm as a transitional type that contains incentives for opportunistic expropriation of assets. These poor incentives are often attributed to family firms in general, but the results in this paper suggest strongly that single-family firms do not have such poor incentives.

The implication of this paper is that relationships among board of directors' members play an important role in determining how firms perform. The "family firm" is the kind of "autocratically-run" firm where the founder of the firm manages and controls all aspects of the firm, resulting in good performance. The "partnership firm" is analogous to an oligopoly where a board of directors can choose to cooperate or where members can pursue their own interests, which may result in a tragedy of the commons. The corporate firm is the best form where all directors on the board pursue shareholder wealth. I have suggested that we apply the ideas in the paper more generally to characterize the relationships among board of directors in developed capital markets. 


\section{Chapter 3}

\subsection{Introduction}

Returns from developed markets, including those in the U.S., Japan and Germany, have been much lower recently than in many emerging markets. In the 1990s, international investors poured money into high-growth emerging markets. Emerging markets played an important role in the 1990s because their economic growth figures were high. Asian equity markets in China, Indonesia, Korea, Philippines, Malaysia, and Thailand increased in value more than threefold between 1990 and 1996, from roughly \$300 billion to \$1.1 trillion. Capital market liberalization in these markets during the 1990s facilitated the flow of funds from international investors and contributed to the increase of capital mobility. Claessens, Djankov, and Lang (2000) show that two thirds of East Asian corporations are family businesses, in the sense that a single family holds a major share of the firm. They conclude that the dominant role of the family enterprise in Asian equity markets indicates weak systems of corporate governance, which may cause some emerging-market investors to decide it is best to avoid family enterprises.

In this paper, I compare three different kinds of investment risks faced by investors in family, partnership, and corporate-style firms. I compare the total risk, measured as variance of return, and systematic risk as measured by the Capital Asset Pricing Model (CAPM), and the Fama French three-factor model. I have used variance of return as the primary measure of total risk. The higher the variance, the higher the risk, since variance indicates the level of uncertainty about the return. My result indicates that family firms are riskier than corporate- 
style and partnership firms, and that partnership firms are riskier than corporate-style firms, in terms of variance of return.

Most financial textbooks separate risk into two categories: systematic risk, and idiosyncratic risk. Systematic risk is related to a firm's beta in the CAPM context. Thus we normally use beta as a measure of how risky an asset is in comparison to the market. The Thai market is small, so I have used both the Thai market as a market return and the world market index as a second measure of market return. My results show that family firms are riskier than the corporate-style firms in Thailand, but not in the world market. It is rational to invest in a riskier asset if it provides a higher return or higher abnormal return on average. The average abnormal returns are positive from the estimation period of 1992 to 1996 . These returns support why Asian market equity had increased value. Finally, I examine whether there are significantly different degrees of risk inherent in the three styles of management using the Fama French three-factor model. I have applied the three factors by using Thai market and U.S. market data downloaded from Kenneth French's website (http://mba.tuck.dartmouth.edu/pages/faculty/ken.french/). The result suggests that family firms are riskier than the other two styles in the Thai market, but the corporate-style firms are riskier in the U.S. market.

In the next section I review some literature about the concept of beta, abnormal return on assets, and the Fama French model. In section 3, I describe the data used in the study. In section 4, I discuss the empirical results. Section 5 concludes. 


\subsection{Literature review}

Harvey and Roper (1999) report that Asian corporate managers increasingly leveraged their companies during the 1990s, despite their declining profit ratios. The authors conclude that the managers "bet" their companies, expecting added leverage to offset declining profits ratios. Since the interest rate of borrowing in foreign currency was much lower than the interest rate of borrowing in domestic currency, the managers gambled that the exchange rate could remain the same. Most articles indicate that managers came mostly from major shareholding families.

\subsubsection{The concept of beta}

The Capital Asset Pricing Model (CAPM) developed by Sharpe (1964) and Lintner (1965) is still the most commonly used method of risk/return evaluation for investors, financial advisor firms, and most financial investment institutions. "The CAPM implies that the expected return of an asset must be linearly related to the covariance of its return with the return of the market portfolio" (Campbell, Lo, and MacKinlay 1997). The covariance of an asset's return with the return of the market portfolio is measured by the beta, which indicates the non-diversifiable of the asset. By construction, the beta for the market is 1.0, meaning that if a single individual asset's beta is 1.0 , then that asset's return is perfectly correlated with the market. If an individual asset is half as volatile as the market, then this asset's beta is equal to 0.5 . Finally, if an individual's asset beta is 2.0 , then that asset is twice as volatile as the market, therefore twice as risky.

I have calculated the beta of each family firm, as well as the market beta for the Thai market. We use the Thai market as only a proxy for the market portfolio, since it should consist of all risky assets, including bonds, precious metals, real estate, human capital, and 
international stocks as per the Roll critique (1977). I define the family beta as the average of the betas calculated from each of the family firms identified in the first essay.

Many economists assert that family firms' use of high debt ratios was the major cause of problem in the Asian financial crisis. As we saw in the first essay, the average debt-toequity ratio is highest in the family firm. For partnership firms the average leverage is lower. For the corporation style of management, average leverage is at the lowest level.

The regression beta is sometimes called the "leveraged" beta, as it does not adjust for the amount of debt used by firms in their capital structure. Debt is used in most capital structures since it provides benefit for a firm. There is a large body of literature concerning capital structure. For example, Modigliani and Miller (MM 1958) show that capital structure is irrelevant to firm valuation in the absence of taxes. Later, in 1963, they showed that because of the tax benefits of debt financing, a firm maximizes its value by employing 100 percent debt financing.

But in the real world we have taxes as well as bankruptcy, and therefore real-world firms' capital structures fall between zero and 100 percent debt. Debt financing adds risk to a firm's equity holder, thus the required rate of return is higher than a firm with 100 percent equity finance.

Since the degree of leverage differs across firms, the unleveraged beta is often calculated using a Hamada equation. Hamada (1969) combined the CAPM with the MM model to show that the required rate of return on a leveraged firm's stock equals the risk-free rate plus a premium for business risk, plus another premium for using debt. To adjust for this, we calculate the average unleveraged beta from each of the three different styles of 
management. The hypothesis tests whether these betas are significantly different from each other.

Other factors besides capital structure have also been identified that may affect expected returns. For example, Fama and French (1995) show that high book-to-market ratios tend to generate a high return and vice versa. However, Chen and Zhang (1998) find that value stocks are riskier because they are usually firms under distress, have high financial leverages, and face substantial uncertainty in future earnings. They claim that these risk characteristics are as powerful as size and book-to-market in explaining cross-sectional differences in return in Pacific Rim markets, including Thailand.

\subsubsection{Estimation Methodology on CAPM}

Two techniques for estimating beta are used here. First, I collect historical price data for Thai listed firms from 1992 to 1996 and calculate the return by subtracting from the stock price in the previous period from the price in the current period, divided by the price in the previous period ignoring the dividend). Although during that period the Thai government did not issue government bonds, data from International Financial Statistics (IFS) show that money market rates in Thailand were comparable to the federal funds rate. I therefore used the Thai money market rate as the risk-free rate. Then I used the basic CAPM equation to calculate the beta for each firm (equation 1).

In the second technique, I collected consumer price index data from the Bank of Thailand to calculate the inflation rate. Then I calculated beta from the CAPM equation using inflation instead of the risk-free rate (equation 2). Then the unleveraged beta is calculated (equation 3 ) since we have at issue family firms using higher debt-to-equity ratios 
than other styles of management. The average unleveraged betas from three different styles of management are tested to determine whether they differ significantly from each other.

The first conclusion drawn from the results is whether the family firm, partnership, and corporation are associated with different degrees of business risk. Alpha is used to calculate the abnormal return on asset since it is equal to realized return minus the expected return.

$$
\begin{aligned}
& \mathrm{R}_{\mathrm{it}}-\mathrm{R}_{\mathrm{ft}}=\alpha_{\mathrm{i}}+\beta_{\mathrm{i}}\left(\mathrm{R}_{\mathrm{mt}}-\mathrm{R}_{\mathrm{ft}}\right)+\varepsilon_{\mathrm{i} 1} \\
& \mathrm{R}_{\mathrm{it}}-\pi_{\mathrm{t}} \quad=\quad \alpha_{\mathrm{i} 2}+\beta_{\mathrm{i} 2}\left(\mathrm{R}_{\mathrm{mt}}-\pi_{\mathrm{t}}\right)+\varepsilon_{\mathrm{i} 2} \\
& \beta_{\mathrm{U}} \quad=\quad \beta_{\mathrm{i}} /[1+(1-\mathrm{T})(\mathrm{D} / \mathrm{S})]
\end{aligned}
$$

where $R_{i t} \quad$ is return on stock $i$ in period $t$

$$
\mathrm{R}_{\mathrm{ft}} \quad \text { is risk free return in period } \mathrm{t}
$$

$\mathrm{R}_{\mathrm{mt}} \quad$ is market return in period $\mathrm{t}$

$\varepsilon_{i 1} \quad$ is the error term in regression equation 1

$\pi_{\mathrm{t}} \quad$ is the inflation in period $\mathrm{t}$

$\varepsilon_{\mathrm{i} 2}$ is the error term in regression equation 2

$\beta_{\mathrm{U}} \quad$ is the unleverage beta

$\beta_{\mathrm{i}} \quad$ is the leverage beta

$\mathrm{T}$ is tax rate

D is the debt

$\mathrm{S} \quad$ is equity

$\alpha_{i} \quad$ is the abnormal return from CAPM model

$\alpha_{\mathrm{i} 2}$ is the abnormal return from inflation equation 


\subsubsection{Fama French three-factor model}

Fama and French (1996) argue that the CAPM cannot explain average returns. They explain average returns from excess market returns and the firm's size, and book to market equity. The "size" factor is the difference between the return on a portfolio of small stocks and the return on a portfolio of large stocks (SMB). The "value" factor is the difference between the return on a portfolio of high-book-to-market stocks "value firm" and the return on a portfolio of low-book-to-market stocks "growth firm" (HML).

Fama and French use HML as a proxy for relative distress. They explain that weak firms with persistently low earnings tend to have high-book-to-market, positive slopes on HML (relatively distressed), and higher future average return; strong firms with persistently high earnings have low-book-to-market, negative slopes on HML, and low future average return. Their results are consistent with rational ICAPM or APT asset pricing. Lakonishok et al. (1994) and Hagen (1995) show that the value premium in average returns is positive because the market undervalues the weak firms and overvalues the strong firms. When these pricing errors are corrected, weak (value) firms have high returns and strong (growth) firms have low returns. Thus I have employed the Fama and French three-factor model as an alternative way to investigate risk. The model is as follows.

$$
\mathrm{R}_{\mathrm{it}}-\mathrm{R}_{\mathrm{ft}}=\alpha_{\mathrm{i}}+\beta_{\mathrm{im}}\left(\mathrm{R}_{\mathrm{mt}}-\mathrm{R}_{\mathrm{ft}}\right)+\beta_{\mathrm{is}} \mathrm{SMB}+\beta_{\mathrm{iv}} \mathrm{HML}+\varepsilon_{\mathrm{it}}
$$

where $R_{i t}$ is return on stock $i$ in period $t$

$\mathrm{R}_{\mathrm{ft}} \quad$ is risk free return in period $\mathrm{t}$

$\mathrm{R}_{\mathrm{mt}} \quad$ is market return in period $\mathrm{t}$

$\alpha_{i} \quad$ is the abnormal return on asset from Fama French model

$\beta_{\mathrm{im}}$ is the market beta 
$\beta_{\text {is }} \quad$ is the size beta

$\beta_{\mathrm{iv}} \quad$ is the book-to-market beta

$\varepsilon_{i t} \quad$ is the error term in regression equation 4

The data set contains both Thai and U.S. returns from 1992 to 1996 . The $\beta_{\text {im }}$ is the same as in the CAPM model. The $\beta_{\text {is }}$ is the "size" factor. To obtain this factor, I ranked firms from the Stock Exchange of Thailand by size, and then designated the largest one-third of the firms as big firms, and the smallest third as small firms. I then calculated the average monthly return of each group and subtracted the average returns of the large firms from the average returns of the small firms.

\subsection{Description of Data}

The analysis in the following sections is based on publicly traded non-financial companies in Thailand in 1996. Bank, finance, and insurance companies are excluded from the sample since it is difficult to measure their Tobin's q. In addition, the government regulates these sectors, which may affect their performances. The stock price, number of shares outstanding, and financial statements were collected from the I-SIMS database produced by the Stock Exchange of Thailand.

The first and last names of the boards of directors were manually collected from Manager Information Services (1996). There were 346 listed companies at the end of year 1996. All firms were included in the sample if they met two criteria: first, the company must have been listed before 1996, which provides necessary data for the study, and secondly, the first and last names of the board of directors are listed in the Manager Information Service. This criterion reduces the sample size to 315 companies. The risk-free rates are collected 
from the International Financial Statistics (IFS) database. The consumer price indexes are collected from The Bank of Thailand. Most researchers use the Treasury bill rate as a riskfree rate. There is no Treasury bill rate for Thailand during the studied period between 19921996, since the Thai Government changed its fiscal policy from budget deficit to balanced budget in 1990, which meant that no treasury bills were issued after 1990. It was not until fiscal year 1999 that the Government reverted to a budget deficit, when the cabinet approved the borrowing of 40 billion baht. Thus, I have used the money market rate as the risk-free rates since it is most comparable to the Federal Funds rate used for U.S. data.

\subsection{Empirical results}

\subsubsection{Results from analysis of the risk and return base on mean and variance}

I measure the mean returns and total risk of the firms from the variance of the returns. It is really a basic way of measuring risk and reward. The return is a measurement of the reward from holding the asset. The risk is measured by dispersion of the monthly return from 1992 to 1996 . The firms are classified into corporation-style, family, and partnership firms. The hypothesis testing is performed to test the mean and variance based on their styles of management. The results show that we cannot reject the hypothesis that the mean returns from these three styles are equal. However, an F-test is performed to test whether the average variance of these three different styles are the same. I conclude that the family firms are riskier than both the corporation and the partnership firms, and that the corporation-style firms are riskier than the partnership firms. 


\subsubsection{The total risk comparison.}

Results from table 3.1 show that the total risk measures on three different styles of management are significantly different from each other. Hypothesis testing between the average variance of return on family style and the average variance return on corporation style is as follows.

$$
\begin{array}{lll}
\mathrm{H}_{\mathrm{o}} & : & \mu_{\text {var_fam }} \leq \mu_{\text {var_corp }} \\
\mathrm{H}_{\mathrm{A}} & : & \mu_{\text {var_fam }}>\mu_{\text {var_corp }} \\
\mathrm{F} \quad= & 1.39 \\
\text { p-value }= & 0.03 \\
\text { Reject null hypotheses }
\end{array}
$$

Second, hypothesis testing between average variance of return on partnership style and average variance return on corporation style is as follows.

$$
\begin{array}{lll}
\mathrm{H}_{\mathrm{o}} & : & \mu_{\text {var_corp }} \leq \mu_{\text {var_part }} \\
\mathrm{H}_{\mathrm{A}} & : & \mu_{\text {var_corp }}>\mu_{\text {var_part }} \\
\mathrm{F} \quad= & 4.28 \\
\text { p-value } & = & 0.00
\end{array}
$$

Reject null hypotheses.

Third, hypothesis testing between average variance of return on family style and average variance return on partnership style is as follows.

$$
\begin{array}{lll}
\text { Ho } & : & \mu_{\text {var_fam }} \leq \mu_{\text {var_part }} \\
\mathrm{H}_{\mathrm{A}} & : & \mu_{\text {var_fam }}>\mu_{\text {var_part }} \\
\mathrm{F} \quad= & 5.91 \\
\text { p-value }= & 0.00
\end{array}
$$


Reject null hypotheses

\subsubsection{Systematic risk from CAPM comparison and abnormal return.}

During the period from 1992 to 1996, the Thai government had not issued Treasury Bills since the government had a balanced budget. The Thai economy can be considered a small open economy thus the risk free rate is perhaps an issue. I use the money market rate as a risk free rate and compare the result with the beta calculated from the inflation CAPM. The calculated beta from the risk-free rate and the calculated beta from the consumer price index are not significantly different from each other. I also use the world market index to obtain a better-defined capital market return. However, family firms have higher debt to equity ratios. Thus the unleveraged beta provides a much better picture of the degree of risk associated with each style.

\subsubsection{Unleveraged beta comparison.}

As in the previous section, I use both the Thai market index and the world market index as proxies for the market in the CAPM model. I calculate the unleveraged beta for each firm then calculate the mean of the unleveraged beta for each style of management and perform hypothesis tests. I find that the average unleveraged betas for family firms are significantly higher than the corporation firms when using the Thai market index as a proxy

for the market (see table 3.2). I fail to reject the hypothesis the mean unleveraged betas for partnership and family firms are the same, and also reject the same equality between partnership and corporation-style firms. When using the world market index, world beta from three different styles of management are also not significantly different from each other (see table 3.2). 
Results from the CAPM risk measurement on three different styles of management show that the unleveraged betas from family firms are significantly riskier than the unleveraged beta from corporation firms. Hypothesis testing between the average unleveraged beta on family style and the average unleveraged beta on corporation style is as follows:

$\begin{array}{lll}\mathrm{H}_{\mathrm{o}} & : \quad \mu_{\mathrm{u}_{-} \text {beta_fam }} \leq & \mu_{\mathrm{u}_{-} \text {beta_corp }} \\ \mathrm{H}_{\mathrm{A}} & : \quad \mu_{\mathrm{u}_{-} \text {beat_fam }}>\mu_{\mathrm{u}_{-} \text {beta_corp }} \\ \mathrm{Z} & =1.35 \\ \text { p-value } & =0.08\end{array}$

Reject null hypotheses at 10 percent confidence level.

\subsubsection{Abnormal return from CAPM}

Alpha is the abnormal return since it is equal to the realized return minus the expected return. When comparing the abnormal stock's returns from the capital asset pricing model, we find that the average abnormal returns from the three styles of management are not significantly different from each other. All three hypothesis testing fail to reject the null hypothesis that average abnormal returns are significantly different from each other. High average abnormal returns in both Thai and world market indicate that CAPM model does not give a good explanation of risk and return. As a matter of fact, for all three styles of management, average abnormal returns in table 3.3 are close to the averages returns from table 3.1 . 


\subsubsection{The Fama French model}

\subsubsection{Fama French Three-Factor as a measure of risk with Thai data}

I use the Fama-French model in two ways. First, I apply the model using the Thai data to classify firms by the size factor and the book-to-market-value factor (see table 3.4). This version is appropriate if the Thai market can be viewed as mostly isolated from other world markets. The Thai Fama-French model is estimated and the required return is as follows. For Corporation-style, Family, and Partnership firms the required returns are 176.56, 222.02, and 198.05 accordingly. The higher the required return, the riskier the firms are. In our case the family style firm is riskier than the other two styles; the partnership firm is the second riskiest type of firm.

The major loading factor is the book-to-market factor for all three styles of management. One implication is that high-book-to-market (value) stocks will require higher return than the low-book-to-market (growth) stocks. The family firms are considered smaller and value firms since the loading factor for size and book-to-market is positive. The results also suggest that family firms are relatively distressed.

\subsubsection{Fama French Three-Factor as a measure of risk with World data}

I also use the data from Kenneth French's website to run the three-factor model. This is appropriate if Thai markets can be thought of as well integrated within the world financial markets (see table 3.4). The required returns for the corporation, family, and partnership firms are 74.57, 71.56, and 69.32 respectively. The world data, however, suggest a different result that the corporation is riskier than the family and the partnership firms. 
The result is similar to the Thai market Fama French in a sense that book-to-market is where the majority of required returns are coming from all three styles of management. Besides family firms are smaller value firms.

\subsubsection{Abnormal return for Fama French model}

The Fama-French alpha is a similar concept to the CAPM alpha, but it is the abnormal return after accounting for the three factors. The results from hypothesis testing are the same as the CAPM. I fail to reject the null hypothesis of equal returns for all styles in all cases. The problem with using the CAPM is that the average abnormal returns are as high as the average return from the estimation periods. Our average absolute pricing errors (intercept or alpha CAPM) of the CAPM are three to four times those of the three-factor model using Thai market. They are also seven to eighteen times those of the three-factor model using world market. Thus CAPM does not give a good explanation of risk and return.

\subsection{Conclusion}

This study has used total return variance, the CAPM, and the Fama-French threefactor model to identify whether the different styles of management are associated with different degrees of risk. We can differentiate the riskiness of the three different styles of management by measuring total risk. The family firms turn out to be riskier than the other two styles of management. We find family firms are riskier than the corporation and partnership firms using the variance of the returns. From CAPM, I find that the average unleveraged betas for family firms are significantly higher than the corporation firms when using the Thai market index as a proxy for the market.

From the CAPM model using the world market, we do not find significant differences in riskiness among family, partnership, and corporate-style firms. The abnormal returns are 
positive in all cases but not significantly different from each other. The averages abnormal returns from Fama French model are also lower (lower absolute pricing errors) than that from the CAPM. The Fama-French model gives a better explanation. This model suggests different results when using Thai and U.S. factors. The family firms are riskier while using Thai data but the corporation is riskier when using U.S. data. However, the Fama-French model implies far smaller abnormal returns and thus appears to explain the risk and return relationship better. Based on these results, the family firms are riskier (and have higher returns) because they are smaller in size and tend to be value firms since they have high loadings on the size and book-to-market-value factors. 


\section{Chapter 4}

\subsection{Introduction}

The recent financial crisis in East Asia provides a natural experiment to identify factors that contribute to the use of bankruptcy as a means of resolving corporate distress. Economic theory, as explained by White (1989), says that bankruptcy laws should serve as a screening process to eliminate only firms that are economically inefficient, whose resources could be better used elsewhere. A financial crisis situation may perhaps accelerate the process toward long-run competitive equilibrium in which only the least-cost firms survive. On the other hand, non-market "crony" relationships may bring other criteria into the process, resulting in a non-optimal outcome.

Many accounts in the popular press placed part of the blame for East Asian firm failures on "crony capitalism," in the form of informal relationships between family-owned enterprises and the banking sector that subverted market processes. However, this purported behavior of banks is difficult to square with a profit motive. If banks are profit-maximizing firms, their primary concern is their own profit, and not the survival of other firms. As Claessens, Djankov, and Klapper (1999) conclude, a bank is likely to force a firm to file for liquidation if by doing so it can recover its losses.

The academic business literature supports this stylized natural history of firms in developing countries. Bhattacharya and Ravikumar (2001) provide a model of family businesses operating with a production technology in which the household's primary human capital is its specific business skill. The founder of a family-owned firm can either bequeath the business and skill to the next generation or choose to sell the business and bequeath the proceeds. Based on their dynamic model, if there are imperfections in primary capital 
market, they predict that family businesses will last longer than businesses with a more dispersed ownership.

In most countries, it is difficult to distinguish family-run companies from other types of management structures using publicly available data. This is, however, not the case in Thailand. Thai law is strict in that it requires that only family members can share the same last names. This allows a researcher to identify family-run firms with some precision from the publicly available listings of directors' names. Thus, we can exploit the unique features of Thai business data to investigate the effect of family control, and interlocking directorates between banks and firms, on the viability of those firms during the East Asian financial crisis of 1997.

In Thailand, as in most other developing countries, firms often follow a similar life cycle. A typical firm begins with certain skills and expertise within a single family in the early stages of the country's economic development. As the business expands and seeks new capital, it may become listed on the Stock Exchange. After the first generation, sons-in-law are included as part of the family. This process adds new last names to the firm's directorship, creating what I refer to here as a "family partnership" firm, in which two or three last names dominate the board of directors.

In this paper, I compare the listed companies from the Stock Exchange of Thailand in 1996 with those that survived the crisis as of 2000 , to examine the effect of family control of firms and the bank-firm relationship on survival rates. This study supports the Bhattacharya and Ravikumar model. My findings suggest that companies whose boards of directors are dominated by one or two families were less likely to file for bankruptcy during the East Asian crisis than companies with a more dispersed directorship. The study also provides 
some evidence that family firms and partnership firms with interlocking directorates with failed banks are less likely to have survived the crisis.

In the next section, I review some of the literature about family businesses, the bankfirm relationship, and firm survival. In section 3, I describe the data used in the study. Section 4 contains a discussion of the empirical results, and section 5 concludes.

\subsection{Literature Review}

There is a large literature discussing the factors that determine the use of bankruptcy as a means of resolving corporate distress. Many of these papers focus on the style of management and the bank-firm relationship. As the financial market and the legal procedures in Thailand are much different than in the United States, I will first provide some background information about Thailand.

\subsubsection{Financial market and bankruptcy process in Thailand}

The financial system in Thailand, as in Japan and Germany, relies mainly on financial intermediaries, including both financial companies and banks. Thus, most Thai managers carefully develop relationships with their bankers, since banks are their primary source of loans. This type of close bank-firm relationship may or may not be the best system for firms. Long-term relationships between banks and firms in which, besides loaning the firm money, the bank may hold equity in the firm and even appoint some of its personnel, are common in Japan and Germany as well as Thailand. Such close firm-bank relationships are described by Weinstein and Yafeh (1998) as an essential feature of a "growth-oriented" financial system." They argue that when access to capital markets is limited, a close bankfirm tie increases the availability of capital to borrowing firms, but does not lead to higher 
profitability and growth for them. Instead, they indicate that the banks appropriate most of the benefits from these relationships.

On the other hand, according to Claessens, Djankov, and Klapper (1999) banks preferentially supply credit to certain family firms. This strong interpersonal relationship can positively influence the timing, severity, and resolution of financial distress for the firm.

The bankruptcy process in Thailand is different from that in United States. U.S. bankruptcy law is designed to create a debtor-friendly system, while the Thai bankruptcy law is a creditor-friendly system. Claessens, Djankov, and Klapper (1999) compare and contrast the different bankruptcy systems in developed countries. Generally, in creditor-friendly systems firms do not file for bankruptcy since they receive no protection, and banks often pursue legal procedures to take control of the distressed firm and recoup their loans. In a debtor-friendly regime, such as the U.S., the original managers of the bankrupt firm continue to manage the firm during reorganization negotiations. In contrast, in a creditor-friendly regime such as Thailand or the U.K., creditors have the power to replace existing managers. As White (1989) explains, the threat of firing gives the manager a strong incentive not to engage in risky projects. The disadvantage for the creditor is that he or she may suffer higher costs of resolving the financial problems, since a new manager may be unfamiliar with the company.

After the financial crisis of 1997, most Thai firms faced financial difficulty. The only sources of finance were the financial intermediaries including banks and financial companies. The devaluation created a serious problem for most firms, especially those who borrowed money from offshore sources. Many of these firms could not even pay interest to the banks, which caused their loans to be classified as non-performing by the banks and generally 
resulted in legal proceedings. The specific legal procedure in each case depended on the bank's preference. Thus banks had the ability to provide friendly legal procedures to firms with which they had close relations.

The Stock Exchange of Thailand (SET) and the Security Exchange Commission of Thailand (SEC) also influence the bankruptcy environment in Thailand. The SET is empowered by the SEC as a secondary market for trading securities that were initially issued and offered for sale to the public in the primary market. The SEC Act (1992) allows the business sector to issue and offer various kinds of securities, namely equities, debt instruments or hybrid instruments for sale to mobilize funds from the public. The SEC plays an important role in setting out policies and approving regulations, such as listing and delisting rules and commission fee structures, for the SET.

Listed shares may be delisted if they do not meet all the SEC's requirements.

Delisting of securities may occur by request of the listed company or where there are grounds for delisting. The delisted company, where there are grounds, may choose to enter into liquidation to dissolve its company or may try to eliminate the grounds for delisting. In this case, the listed company must prepare a delisting rehabilitation plan in accordance with the guidelines prescribed by the SEC.

After the Asian Financial crisis, the financial conditions of many listed companies were serious. According to the rules and regulation of the SEC, a listed company will be put in the rehabilitation sector if "the latest audited financial statement or consolidated financial statements shows that the shareholder's equity is lower than zero". 


\subsubsection{Does Probability of survival depend on style of management?}

After the Asian financial crisis, many financial intermediaries were liquidated, while others were put in the "rehabilitation sector," which in Thailand is a status midway between filing for bankruptcy for reorganization and liquidation in U.S. law. Firms in rehabilitation have to make a choice and come up with an action plan, which management typically develops and offers to shareholders for approval. This paper investigates which styles of management are associated with a higher probability of surviving this process.

The family style of management is common in East Asia and has become a major focus of analyses of the crisis (see, for example, Faccio, Lang, and Young, 2001). Khaemasunun (2003) also presents evidence that family firms tend, on average, to have high financial performance. Here, we pursue the question of whether family firms can survive the financial crisis better than the other styles of management.

\subsubsection{Bank-firm relationship: Benefit or threat?}

We consider both failing and surviving banks. The banking industry is regulated by the Bank of Thailand, which shuts down failing banks immediately after it receives information that indicates their failure. A surviving bank may or may not exhibit "crony" behavior inconsistent with profit maximization. Many banks have directors that also serve as directors of firms in the non-financial sector. Having a director in common with a failed bank may harm the reputation of a firm, since the bank director may be blamed for the bankruptcy of the bank. The poor reputation of the failed banker on its board may reduce the ability of the firm to obtain financing needed to avoid bankruptcy or liquidation. My empirical results provide support for the proposition that a close relationship with a failed bank increases the probability that a firm will be delisted. 
Kim (2002) shows from Korean data that firm size and the largest shareholder's shares have favorable effects on the survival probability of a firm. On the other hand, Opler and Titman (1994) argue that a highly leveraged firm is especially vulnerable, as it will lose substantial market share to more conservative competitors during industrial slumps. Following Kim and Opler and Titman, I therefore use firm size, leverage, and industry dummy variables to help explain differences in bankruptcy probability among firms.

\subsection{Description of data and variables}

\subsubsection{Description of data}

The analysis in the following sections is based on publicly traded non-financial companies in Thailand in 1996 and 2000. Bank, financial and insurance companies are excluded from the sample since the government regulates these sectors, as they may affect the survival of companies. The stock price, number of shares outstanding, and financial statements were collected from the I-SIMS database produced by the Stock Exchange of Thailand. There were 346 and 382 listed companies at the end of 1996 and 2000, respectively. All firms were included in the sample if they met two criteria: first, the company must have been listed before 1996; and second, both the first and last names of all members of the board of directors must have been listed in the Manager Information Service (1996). (For the year 2000, the first and last names are from the I-SIMS database.) Application of these two criteria reduced the sample size by approximately $10 \%$, to 315 companies at the end of year 1996. From 315 companies at the end of 1996, 88 were included in the rehabilitation sector and 42 were delisted at the end of year 2000. 
There are a few reasons to choose the year 1996 as the beginning period and the year 2000 as an ending period of this study. First, the year 1996 directly precedes the Asian Financial Crisis of 1997. This crisis was triggered by a sudden devaluation of the baht. From 1984 to 1997, the Bank of Thailand's exchange rate policy had been to hold the baht stable against a basket of currencies denominated by the dollar. In 1993, the Bangkok International Banking Facilities (BIBF) was established allowing local and foreign commercial banks in Thailand to take deposits or borrowings in foreign currencies from abroad and lend them in Thailand. Most funds were spent on real estate and property.

With heavy speculation, the Bank of Thailand fell short of resources while it was trying to support the baht. On $2^{\text {nd }}$ July 1997, the baht was allowed to float. At the same time, the International Monetary Fund offered a $\$ 17.2$ billion package to stabilize the Thai economy and allow it to meet its short-term obligations. The crisis forced the government and businesses to focus on solving fundamental problems such as non-performing loans and rising inflation. Besides, the Thai government imposed strict rules that were intended to reduce the risk of financial institutions with bad loans. The political uncertainties and volatility of regional currencies pushed the baht steadily downwards against the U.S. dollar through 2000, but the crisis is generally believed to have ended in 1999 . The year 2000 is the last year of the study because the currency became stable after 2000 .

\subsubsection{Description of variables}

\subsubsection{Dependent variables}

To measure company survival, I have used information from the I-SIMS database produced by the Stock Exchange of Thailand (SET). I identified the listed firms of 1996 that 
survived the Asian Financial Crisis and were therefore still listed at end of 2000. I also attempt to identify the reasons why certain firms failed and others survived.

The BANKRUPT dummy variable identifies firms that were in the "rehabilitation sector" in 2000. It equals zero for listed companies that are not in the rehabilitation sector at the end of 2000, and one for listed companies that are in the rehabilitation sector.

Also, the dummy variable "LIQUIDATION" equals one for firms that were delisted from the Stock Exchange of Thailand by 2000. Firms are subject to delisting by the SET if they are no longer qualified according to SEC requirements. Listed firms whose equity is less than zero after the Asian Financial crisis can choose to be delisted from their firms or continue as rehabilitation firms. The delisted firms are liquidated in a way that is similar to filing for Chapter 7 under U.S. law. The continuing rehabilitation firms, as in Chapter 11 under U.S. law, are allowed to come up with plans to solve their problem within two years. The period can be extended as long as firms are making progress. The "LIQUIDATION" variable equals zero if they continue with their rehabilitation plans to recovery.

\subsubsection{Explanatory variables}

Data from Thailand offer a unique advantage for this study, since legal requirements in Thailand allow researchers to uniquely identify Thai last names to members of a single family (see Appendix 1). The unique Thai law originated in the migration of many Chinese people to Thailand. Many of them had the same last name or even the same first and last name without knowing each other, which caused confusion. To solve this problem, Thai law allowed each family to register a new unique Thai last name. Thai last names are lengthy for this reason, but it is easy to identify family directors by their last name. 


\section{The style of management dummy variables}

For this study, we classified companies into three categories: Family, Partnership, and Corporation, using data about the last names of directors. Family firms are defined as those whose board of directors has only one family with more than one member on the Board of Directors. If a firm's Board of Directors has two or more families with more than one Board member, then it is a partnership firm. If a firm's Board of Directors has no families with multiple members on the Board, it is called a corporation, for purposes of this study.

\section{The bank-firm relationship variables}

Recall that the financial system in Thailand relies mainly on financial intermediaries, including both financial companies and banks. After the Asian Financial crisis, many financial intermediaries were closed down. The explanatory variable "BankDirF" is used indicate a close relationship between a listed company and a financial institutions that survived the Crisis (survive-bank-firm). "FBankDirF" is used to indicate a close relationship between a listed firm and a failed financial institution (failed-bank-firm).

I use the membership lists of the Boards of both the firms and the financial institutions to construct these variables. First, I check to see if one or more of the directors of the listed firm and the surviving financial institutions have the same last name. If they do, we then count the number of directors of the listed companies on the Board of financial institutions. The "BankDirF" variable is calculated as the number of financial-institution related directors of the listed firm, divided by that is the total number of the firm's director. The "FBankDirF" is calculated in the same manner as the "BankDirF" but with respect to the failed-bank-firm relationship. We also define two dummy variables as 'DFBankDir' and "DBankdir". The "DBankDir" will take zero if there is no relationship between directors of 
surviving financial intermediaries and the firm. The "DFBankDir" is defined in the same manner as the "DBankDir" but to the failed-bank-firm.

I also create the conditional variables "BANKFAM" and "BANKPART", to indicate family and partnership firms, respectively, that have a relationship with the surviving financial intermediaries. Specifically, "BANKFAM" equals one for family firms that had a relationship with at least one surviving financial intermediary. It equals zero if the firm is either not a family firm, or has no relationship with surviving banks. The meaning of the BANKPART variable is analogous to BANKFAM, but for partnership firms.

There are a few firms listed as under rehabilitation in 1996. Thus I create the variable "BAD96" as a firm listing under rehabilitation sector in 1996. It equals to zero if the firm is listed under normal condition. It equals to one if a firm listed under rehabilitation in 1996.

\subsubsection{Control variables}

The Stock Exchange of Thailand defines 31 categories of industries, which I combine into five industry sectors. The agriculture sector consists of agriculture, food and beverage. The commerce sector comprises of commerce, packaging, pharmaceutical products and cosmetic industry categories. The construction industry sector consists of building materials, household goods, and property development industries. The manufacturing sector includes chemicals and plastics, electrical products and computers, electrical components, jewelry and ornaments, machinery and equipment, mining, printing and publishing, pulp and paper, textile, vehicles and parts industries. The service sector consists of communications, energy, entertainment and recreation, health care services, hotel and travel services, professional services, and transportation. 
The SIZEA variable is measured by the natural logarithm of total assets. From our descriptive data, the average size of the listed firms within each sector, ranked from smallest to the largest as measured by total assets are: agriculture, commerce, manufacturing, construction, and service. Leverage is measured as the book value of the total debt divided by the book value of equity. It is lowest in the service sector and highest in the construction sector.

\subsection{Econometric Model and Empirical Results}

In this part, I test whether the different styles of management help to explain the probability of the survival of a firm through the financial crises. In particular, I am interested in whether management style and relationship to bankers help determine the survival of the firm. The beginning year for the study is 1996 , just prior to the Crisis. This is the year for which I identify the style of management of all the firms. The ending period is 2000 , following the Crisis, when I identify which companies survived the financial crisis.

I use two dummy variables to indicate the survival and health of a firm through the Crisis. If a company listed in 1996 is still listed normally in 2000, then it survived the financial crisis, and the variable BANKRUPT equals zero for that firm. If the 1996 listed company has been put in the rehabilitation sector as of 2000 , it is considered not to have survived the financial crisis by this criterion, and its value of BANKRUPT is set to one.

The second indicator of firm survival is called "LIQUIDATION." If a firm that was in rehabilitation in 1996 could not reorganize, it was delisted and LIQUIDATION is set equal to one. For firms that remain in rehabilitation in 2000, LIQUIDATION is set equal to zero. (Thus, LIQUIDATION is defined only if BANKRUPT equals one.) 
Out of the 315 firms in the data set, 88 firms were under rehabilitation, and 42 of those firms were delisted and liquidated.

\section{Binomial Probit model}

I first consider a binomial probit model to identify whether a firm is listed as normal or is classified as in rehabilitation. The dependent variable, BANKRUPT is equal to zero if the firm is in normal condition and equal to one if the firm is in the rehabilitation sector. Most of the independent variables are the same as those used in Khaemasunun (2003), since they explain the performance of the firms, and performance may be presumed to be highly related to survival. The style dummy variables are used to classify the firm as family, partnership, or corporate-style. The control variables are firm size, leverage, Tobin's q, and industry dummies sector.

The variable LIQUIDATION, equal to one if the bankrupt firm is subsequently liquidated, is the dependent variable in the second equation. There are a few differences between the BANKRUPT and LIQUIDATION equations. The LEVERAGE variable (debt/equity ratio) is left out of the LIQUIDATION equation because only firms in rehabilitation can be liquidated. Most firms in rehabilitation negotiate with banker to reduce the amount of debt and interest obligations on their books. Reducing part of the debt makes debt difficult to measure. Thus, the LEVERAGE variable, which is measured as of 1996, is not included in the LIQUIDATION equation because of its inaccuracy. Likewise, during rehabilitation firms normally try to restructure their capital by selling many of their assets, especially unproductive assets. Thus the variable SIZEA is an inaccurate indicator of the size of a firm in rehabilitation, and it is not included in the estimation. 
The independent variables in this second equation also contains the bank-firm relationship variables that are designed to address whether or not a close relationship with a financial institution helps or hurts the firm that is in rehabilitation. BAD96 variable is added to this equation to control for firms that were in trouble before the financial crisis. The two probit equations are as follows:

LIQUIDATION $=\alpha_{1}+\gamma_{1}$ (Controls $)+\beta_{1}($ Style dummies $)+\delta_{I}($ Bank-firm relations $)+\varepsilon_{1}$ BANKRUPT $=\alpha_{2}+\gamma_{2}$ (Controls $)+\beta_{2}$ (Style Dummies $)+\delta_{2}($ Bank-firm relations $)+\varepsilon_{2}$

\section{Bivariate Probit Model with Sample Selection}

The second set of estimates employs a two-step bivariate probit model on the same equations. The variable LIQUIDATION, equal to one if the bankrupt firm was subsequently liquidated, is the dependent variable in the second equation, but, because firms are only liquidated after they fail at rehabilitation, the second equation includes only observations for firms that were in rehabilitation. The system appears as follows:

LIQUIDATION $=\alpha_{1}+\gamma_{1}($ Controls $)+\beta_{1}($ Style dummies $)+\delta_{I}($ Bank-firm relations $)+\varepsilon_{1}$ BANKRUPT $=\alpha_{2}+\gamma_{2}($ Controls $)+\beta_{2}$ (Style Dummies $)+\delta_{2}($ Bank-firm relations $)+\varepsilon_{2}$

$$
\varepsilon_{1}, \varepsilon_{2} \sim \operatorname{BVN}(0,0,1,1, \rho),
$$

$($ LIQUIDATION) is observed only when BANKRUPT $=\mathbf{1}$.

Note that all firms that are at risk for liquidation must be bankrupt first: i.e., only firms for which BANKRUPT equals 1 are included in the LIQUIDATION equation. The first equation is designed to indicate which factors help explain firms' ability to avoid rehabilitation. The second equation is designed to indicate which factors help explain the delisting (liquidation) decision. 
A bivariate probit model is used as it allows the two equations to have correlated disturbances, which increases the efficiency of the estimation. Also, in this case the bivariate probit corrects for potential bias due to sample selection in the second equation, data on LIQUIDATION might be observed only when BANKRUPT equals one.

\section{Results}

The first and second column of table 4.2 presents the result from the binomial probit model on the BANKRUPT variable. The effect of a close relationship between the firm and bankers is the same whether that relationship is indicated by proportional variables ("BankDirF" and "FBankDirF") or dummy variables ("DBankDir" and "DFBankDir"). The negative and significant coefficients on FAMILYD and PARTNER indicate that family firms and partnership firms are less likely to go into rehabilitation than corporate-style firms. The size of the firms and the "Tobin's q" also have negative and statistically significant effects at the $10 \%$ level of significance, indicating that bigger firms may have a lower chance of going bankrupt. In addition, if the achieve a higher Tobin's q (which may indicate a successful investment strategy), they further lower their chance of going bankrupt. The LEVERAGE variable's coefficient is positive and significant at the $1 \%$ level, which indicates that firms with higher leverage and higher interest obligations also may have a higher chance of bankruptcy. The results indicate that agriculture, construction, and manufacturing industries may have a higher chance of bankruptcy than do firms in the service industry.

The third column of Table 4.2 contains binomial probit results for the LIQUIDATION variable. Negative coefficients on the variables "BANKFAM" and "BANKPART" indicate that family and partnership firms that had close relationships with non-failing financial intermediaries had a lower chance of delisting. The variable 
"FbankDirF" has a positive and significant coefficient, indicating that firms have a higher chance of liquidation if there is a relationship with failed banks, but not with successful banks. The fourth column indicates a similar result with the dummy variable that indicates a firm relationship with a failed bank (DFBankDir). The variable "BAD96" has a positive and significant coefficient in all specifications, indicating that firms that were in rehabilitation before 1996 also had a higher chance of liquidation.

Table 4.3 presents results from the bivariate probit model with sample selection. As expected, results from the BANKRUPT equation are substantially unchanged from the binomial probit results reported in Table 4.2. In the LIQUIDATION equation, the relationship variable "DFBankDir" again has a positive and significant coefficient, indicating that firms have a higher chance of liquidation if there is a relationship with failed banks, but not with successful banks. However, the coefficients on BANKFAM and BANKPART become insignificant, thus casting doubt on the willingness of banking-system "cronies" to bail out failing firms.

\subsection{Conclusion}

Family and partnership firms use more leverage than corporate-style firms. But to get loans from bankers, firms must have prospects for future income that convince financial institutions to lend them more money. Highly leveraged firms have a higher chance of getting themselves in trouble, especially during economic downturns, as noted by Opler and Titman (1994). The ability to draw on family resources and personal relationships with financial firms could cushion this effect. On the other hand, reciprocal obligations of the firm to partners who are failing can create dangers for the firm. Regression results in this 
paper illustrate the benefits and pitfalls of family ties among firms. While family and family partnership firms appear to have a significantly higher chance of avoiding bankruptcy, I find little evidence that family ties with bankers improve a firm's chance of survival, although having a close relationship with a failing bank appears to increase a firm's chances of liquidation.

Bankers normally get involved with listed firms, by placing personnel on their boards of directors in order to increase their ability to monitor their clients and investments. When those banks get in trouble, they have an enhanced ability to force the firms into liquidation. Having a failed banker on the board of directors therefore increases the chance of delisting, perhaps in part because they can decrease the chance that the firm can get new loans from more successful banks. In this way, a close relationship with a bank can actually create a threat to the firm instead of a benefit.

Thus, relationship among members of the board of directors plays an important role in determining how firms survive. The "family firm" and the "partnership firm" are strongly motivated to survive, as they represent family traditions and family empires. Corporate-style management, on the other hand, may be more likely to exhibit profit-maximizing behavior in a bankruptcy. Professional managers, with their smaller stakes in the firm, can more easily move on. 


\section{Chapter 5}

\subsection{Summary and Conclusions}

The primary contributions of the dissertation are a better definition of the family business, and more nuanced conclusions about its strengths and weaknesses. The first essay indicates that family businesses can perform as well as more broadly owned, modern corporate-style firms. Partnership firms did not perform as well as the other two styles, perhaps because rival families treat them as a commons. Family firms are smaller and, borrowing more money, require better prospects for future growth. These prospects are reflected in Tobin's q, and a higher Tobin's q is associated with better firm performance, as measured by a variety of accounting measures and market returns. As indicated in the regression results, family and corporate-style firms have significantly higher Tobin's q than family partnership firms do. Unlike the partnership firms, with a lower Tobin's q, indicates lower prospects for future profits. This transitional type contains incentives for opportunistic expropriation of assets.

This essay suggests that the relationships among board of directors' members play an important role in determining how firms perform. The "family firm" is representing the kind of "autocratically-run" firm where the founder of the firm manages and controls all aspect of the firm, resulting in good performance. Running a business needs a good leader. Especially since most of the directors have less experience than their grandfather. The "partnership firm" is where a board of directors can choose to cooperate or where member can pursue their own interests. Mostly, this style will end up in a prisoner's dilemma situation. This is perhaps a good lesson for brother-in-law or real partner to cooperate. A brother may rely on the integrity of his sister but not his brother-in-law. The corporate firm is the best format, 
where all directors on the board pursue shareholder wealth. The different expertise from each director contributes to the performance of the firms.

In the second essay, the foreign investment is necessary for a developing economy like Thailand. Two-third of listed firms are in the so-called "family business." I try to differentiate the family and partnership styles of management. For risk analysis, we cannot differentiate the riskiness of the three different styles of management by using the total risk measurement. Using the world market return is a good application to analyze the return in CAPM context. We conclude that family firms are less risky than the partnership and corporation styles of management. From the result, the mean of the unleverage beta of the family style of management firms are significantly lower in value than the corporation and the partnership style of management firms. Thus, the family firms are less risky than the other two styles of management. The negative beta sign is good since it provides a good diversification for holding Thai asset. It is necessary to emphasize that Thai family firms are good investments. In addition, the mean of the abnormal return of the family firms are significantly higher than the partnership style and the corporation style.

Finally, the third essay explores the strength of family firms and family partnerships in the face of a powerful economic shock. The results make sense in that directors are the decision-makers of the firm, and the incentives of the family directors are more in line with managers in the corporate style, and have more of a personal stake in the continuance of the firm. Thus, the probability of survival of family firms and partnership firms is greater than it is for the corporate style. Though, family firms and the partnership firms use more leverage than the corporate firms do. The lesson for higher leveraged firms is that they have a higher chance to get themselves in trouble especially during economics down turn. 


\subsection{Directions of future research}

Studies about board of directors of firms are well documented in many areas. But the relationship among them will perhaps enrich the field. Our study provides the basic implication that the relationships among board of directors' members play an important role in determining how firms profit, risk and probability of survival. Our future study is to check the robust of our result and extend it to apply the methodology to other markets.

The robust of result is necessary to pursue. The availability of data is crucial for the studies, for example, panel data analysis will reconfirm the contribution of this research. We need more than a cross sectional data with only one year of director information. To confirm the continuance of the same family, we need to have the director information through the whole periods of study. In chapter two, we assume the structure of board of directors in year 1996 as a measure of style of management though the period of study starts from 1992 to 1996. In chapters three and four, we apply the same principle, identify the style of management. It is a reasonable assumption, but to trace the family business is fascinating.

The study is not necessary to apply only to the Thai data. We only need to be able to identify the relationship among the board of director. There are more family firms than you can imagine. For example, listed firms in East Asia and Europe comprise of more than half of family business as discussed by Claessens, Djankov, and Lang (2000). How should we really classify these family businesses? It would also be very interesting to apply this methodology with the U.S. data. Since, U.S. market is supposed to be the most transparent. The information should be available to investigate. Family business term is used in many inappropriate situations. The confusion comes with high costs and it should end. 


\section{References}

Anderson, R. C., Reeb D. M., "Founding-Family Ownership and Firm Performance: Evidence from the S\&P 500." The Journal of Finance, vol. LVIII, NO.3, 2003, 1301-1328.

Bhattacharya, U., Ravikumar, B., "Capital Markets and the Evolution of Family Businesses." Journal of Business, Vol. 74, No.2, 2001, 187-219.

Campbell, J. Y., Lo, A. W., and MacKinlay, C., The Econometric of Financial Markets, Princeton University Press, Princeton, N.J., 1997.

Chandler, A. D., Jr., The visible hand: the managerial revolution in American business Cambridge, Mass.: Harvard University Press, 1977.

Chen, N., and Zhang, F., "Risk and Return of Value Stocks." The Journal of Business, Volume 71, Issue 4, 1998, 501-535.

Claessens, S., Djankov, S., Klapper, L., "Resolution of Corporate Distress: Evidence from East Asia's Financial Crisis." World Bank Policy Research Working Paper 2133, 1999.

Claessens, S., Djankov, S., Lang, L., "The separation of ownership and control in East Asian Corporations." Journal of Financial Economics 58, 2000, 81-112.

Claessens, S., Djankov, S., Xu, L., "Corporate Performance in the East Asian Financial Crisis." The World Bank Observer, vol.15, no. 1, 2000, 23-46.

Claessens, S., Djankov, S., Lang, L., "The separation of ownership and control in East Asian Corporations." Journal of Financial Economics 58, 2000, 81-112.

Faccio, M., Lang, L., Young, L., "Dividends and Expropriation." The American Economic Review, vol. 91, no. 1, 2001, 54-78.

Fama, E. F., "Risk-Adjusted Discount Rates and Capital Budgeting Under Uncertainty." Journal of Financial Economics, Volume 5, 1977, 3-24.

Fama, E. F., and French, K., "Size and Book to Market factors in Earnings return." Journal of Finance, Volume 50, Issue 1, 1995, 131-155.

Fama, E., Jensen, M., "Separation of Ownership and Control." Journal of Law \& Economics, vol. 26, 1983, 301-325.

Greene, W. H., Econometric Analysis, $4^{\text {th }}$ edition, Prentice Hall: Upper Saddle River, NJ, 2000. 
Hamada, R. S., "Portfolio Analysis, Market Equilibrium and Corporation Finance." The Journal of Finance, Volume 24, Issue 1, 1969, 13-31.

Harvey C. R., Roper A. H., "The Asian Bet.” Financial markets and development: The crisis in emerging markets, Brookings Institution Press; Washington, D.C., 1999, 29-115.

Johnson, S., Mitton, T., "Cronyism and Capital Controls: Evidence from Malaysia." Journal of Financial Economics, Vol. 67, Issue 2, 2003, 351-382.

Mankiw, N. G., Macroeconomics, $4^{\text {th }}$ edition, New York, NY: Worth Publishers, 2000.

Kim, Y., Park, S.G., Wang, G. H., Joung, S., "A Study of the Determinants of Survivorship of Listed Companies in Korea." The Journal of Economics Research, Vol. 7, 2002, 161-176.

Klein, A., " Firm performance and board committee structure." Journal of law and Economics, Vol. XLI, 275-303, 1998.

Lim, U., "Ownership Structure and Family Control in Korea Conglomerates." Asian Financial Crisis, Vol.1, 2000, 379-410.

Lintner, J., "The Valuation of Risk Assets And the Selection of Risky Investments in Stock Portfolios and Capital Budgets." The Review of Economics and Statistics, Volume 47, Issue $1,1965,13-37$.

McConaughy, D., Matthews, C., Filako, A., "Founding Family Controlled Firms: Performance, Risk, and Value.” Journal of Small Business Management Vol. 91(1), 2001, 31-49.

Mitton, T., "A Cross-Firm Analysis of the Impact of Corporate Governance on the East Asian Financial Crisis.” Journal of Financial Economics Vol. 64, 2002, 215-241.

Miller, M., and Modigliani, F., "The Cost of Capital, Corporation Finance and the Theory of Investment." American Economic Review, 1958, 261-297.

, "Corporate Income Taxes and the Cost of Capital: A

Correction." American Economic Review, 1963, 433-443.

Opler, T.C., Titman, S., "Financial Distress and Corporate Performance." The Journal of Finance, Vol. 49, No. 3, 1994, 1015-1040.

Palley, T., "The Stock Market and Investment: another look at the micro-foundations of q theory." Cambridge Journal of Economics, Vol. 25, 2001, 657-667.

Porta, R., Silanes, F., Shleifer, A., Vishny, R., "Law and Finance.” The Journal of Political Economy, Vol. 106, Issue 6, 1998, 1113-1155. 
Roll, R., "A Critique of the Asset Pricing Theory's tests." Journal of Financial Economics, Volume 4, 1977, 129-176.

Sharpe, W., F., "Capital Asset Prices: A Theory of Market Equilibrium under Conditions of Risk." The Journal of Finance, Volume 19, Issue 3, 1964, 425-442.

Shleifer, A., Vishny, R., “A survey of Corporate Governance.” The Journal of Finance, Vol. 52, Issue 52, 1997, 737-783.

Suehiro, A., "Family Business Reassessed: Corporate Structure and Late-starting Industrialization in Thailand." The developing Economies, Vol. 31, Issue 4, 1993, 378-407.

Weinstein, D., Yahef, Y., "On the Cost of a Bank-Centered Financial System: Evidence from the Changing Main Bank Relationships in Japan." The Journal of Finance, Vol. 53, No. 2., 1998, 635-672.

White, M., "The Corporate Bankruptcy Decision." Journal of Economics Perspective, Vol. 3, No. 2, 1989, 129-151.

Wiwattanakantang, Y., "An Empirical Study on the Determinants of the Capital Structure of Thai Firms." Pacific-Basin Finance Journal, Vol. 7, 1999, 371-403.

Wiwattanakantang, Y., "Controlling Shareholders and Corporate Value: Evidence from Thailand.” Working Paper Series, No. 2001-4, Institute of Economic Research, Hitotsubashi University, 2001.

Wiwattanakantang, Y., "The Equity Ownership Structure of Thai Firms." Working Paper Series, No. 2001-8, Institute of Economic Research, Hitotsubashi University, 2000.

Yamlamai, W., "Law of person's identification.” Thesis (LL.M.), Chulalongkorn University, (in Thai), 1990.

Yurtoglu, B., "Ownership, Control and Performance of Turkish Listed Firms." Empirica, Vol.27, 2000, 193-222. 
Table 2.1: Sample Descriptive Statistics

\subsubsection{A: Industrial composition and characteristics of companies listed in the sample (1996).}

\begin{tabular}{|l|l|}
\hline INDUSTRY & NO. OF COMPANIES \\
\hline Agriculture & 29 \\
\hline Building material & 31 \\
\hline Chemicals and Plastics & 12 \\
\hline Commerce & 14 \\
\hline Communication & 9 \\
\hline Electrical products and computer & 12 \\
\hline Electrical components & 7 \\
\hline Energy & 8 \\
\hline Entertainment and recreation & 6 \\
\hline Food and beverages & 27 \\
\hline Health care services & 11 \\
\hline Hotel and travel services & 12 \\
\hline Household goods & 8 \\
\hline Jewelry and ornaments & 4 \\
\hline Machinery and equipment & 5 \\
\hline Mine & 2 \\
\hline Packaging & 17 \\
\hline Pharmaceutical product and cosmetic & 2 \\
\hline Printing and Publishing & 9 \\
\hline Professional service & 1 \\
\hline Property development & 37 \\
\hline Pulp and paper & 4 \\
\hline Textile & 29 \\
\hline Transportation & 6 \\
\hline Vehicles and parts & 8 \\
\hline Others & 5 \\
\hline Total & 315 \\
\hline
\end{tabular}


2.1.1.B: Descriptive information of 315 listed companies in the sample.

\begin{tabular}{|c|c|c|c|c|}
\hline Variable & Mean & Std. Dev & Minimum & Maximum \\
\hline Total asset & 6007 & 13434 & 248 & 144838 \\
\hline Total liability & 3644 & 9621 & 14 & 114858 \\
\hline Equity & 2362 & 4283 & -2405 & 36615 \\
\hline Total revenue & 2619 & 5168 & 24 & 61367 \\
\hline Leverage & 1.48 & 3.10 & -6.92 & 50.27 \\
\hline Gmargin & 0.30 & 0.21 & -0.54 & 0.96 \\
\hline ROA & 0.0029 & 0.21 & -2.07 & 0.36 \\
\hline ROE & 0.0021 & 0.82 & -12.43 & 2.63 \\
\hline Excess St-r & 19.59 & 85.35 & -54.82 & 986.68 \\
\hline Tobin's q & 0.63 & 0.71 & 0.03 & 5.32 \\
\hline
\end{tabular}

2.1.1.C: Number of firms by style of management in five industry sectors.

\begin{tabular}{|c|c|c|c|c|}
\hline Industry & Family & Partnership & Corporation & Total \\
\hline Agriculture & 30 & 9 & 17 & 56 \\
\hline Commerce & 18 & 5 & 10 & 33 \\
\hline Construction & 37 & 13 & 31 & 81 \\
\hline Manufacturing & 44 & 21 & 27 & 92 \\
\hline Service & 20 & 6 & 27 & 53 \\
\hline
\end{tabular}


Table 2.2 Descriptive information of firms by styles of management

\begin{tabular}{|c|c|c|c|c|c|}
\hline \multirow{3}{*}{ Total asset } & & Family & Partner & Corporation & Crony \\
\hline & Mean & 4658 & 7376 & 7142 & 5381 \\
\cline { 2 - 6 } & Std Dev & 9138 & 15551 & 16706 & 11229 \\
\cline { 2 - 6 } & Minimum & 278 & 421 & 248 & 278 \\
\cline { 2 - 6 } & Maximum & 85913 & 100636 & 144838 & 100636 \\
\hline \multirow{4}{*}{ Total liability } & Mean & 2719 & 4510 & 4458 & 3195 \\
\cline { 2 - 6 } & Std Dev & 5535 & 10348 & 12950 & 7154 \\
\cline { 2 - 6 } & Minimum & 24 & 129 & 14 & 24 \\
\cline { 2 - 6 } & Maximum & 51363 & 64020 & 114858 & 64020 \\
\hline \multirow{6}{*}{ Equity } & Mean & 1938 & 2866 & 2684 & 2185 \\
\cline { 2 - 6 } & Std Dev & 3823 & 5447 & 4210 & 4323 \\
\cline { 2 - 6 } & Minimum & -2405 & 218 & -1006 & -2405 \\
\cline { 2 - 6 } & Maximum & 34550 & 36615 & 29979 & 36615 \\
\hline \multirow{6}{*}{ Leverage } & Mean & 1.725 & 1.417 & 1.190 & 1.643 \\
\cline { 2 - 6 } & Std Dev & 4.293 & 1.035 & 1.396 & 3.716 \\
\cline { 2 - 6 } & Minimum & -5.972 & 0.047 & -6.919 & -5.972 \\
\cline { 2 - 6 } & Maximum & 50.266 & 4.949 & 7.432 & 50.266 \\
\hline \multirow{2}{*}{ \# Obs } & & 149 & 54 & 112 & 203 \\
\hline
\end{tabular}

Table 2.2A Hypothesis Testing to Detect a Statistical Difference Among the True Proportion Means from Three Different styles of management.

$\begin{array}{lll}\mathrm{H}_{\mathrm{o}} & : & \mu_{\text {prop_fam }}=\mu_{\text {prop_corp }}=\mu_{\text {prop_part }} \\ \mathrm{H}_{\mathrm{A}} & : & \mu_{\text {prop_fam }} \neq \mu_{\text {prop_corp }} \neq \mu_{\text {prop_part }}\end{array}$

Model: prop $=$ famtype

\begin{tabular}{|c|r|r|r|r|r|}
\hline Source & DF & SS & MS & F & Pr $>$ F \\
\hline Model & 2 & 4.169 & 2.084 & 178.2 & 0.0000 \\
\hline Error & 311 & 3.638 & 0.011 & & \\
\hline Total & 313 & 7.807 & & & \\
\hline
\end{tabular}

ANOVA Weighted for Unequal Variances

$\begin{array}{llll}\text { F } & \text { Df num } & \text { Df denom } & \text { Pr }>\text { F } \\ 255.31 & 2 & 111.2 & 0.0000\end{array}$

Reject null hypotheses 
Table 2.3 Descriptive information of firms by industry sectors: Agriculture, Commerce, Construction, Manufacturing, and Service sectors.

\begin{tabular}{|c|c|c|c|c|c|c|}
\hline \multicolumn{2}{|c|}{} & Agriculture & Commerce & Construction & Manufacturing & Service \\
\hline Total asset & Mean & 2071 & 3759 & 8349 & 4605 & 10420 \\
\cline { 2 - 7 } & Std Dev & 2415 & 4744 & 13431 & 10818 & 23145 \\
\cline { 2 - 7 } & Minimum & 385 & 336 & 248 & 294 & 373 \\
\cline { 2 - 7 } & Maximum & 16394 & 19210 & 87858 & 100636 & 144838 \\
\hline Total liability & Mean & 1189 & 2124 & 5530 & 2747 & 5861 \\
\cline { 2 - 7 } & Std Dev & 1430 & 3108 & 9905 & 6936 & 17199 \\
\cline { 2 - 7 } & Minimum & 60 & 56 & 58 & 14 & 24 \\
\cline { 2 - 7 } & Maximum & 8647 & 13441 & 70172 & 64020 & 114858 \\
\hline \multirow{5}{*}{ Equity } & Mean & 882 & 1634 & 2819 & 1858 & 4559 \\
\cline { 2 - 7 } & Std Dev & 1255 & 1975 & 3973 & 3955 & 6833 \\
\cline { 2 - 7 } & Minimum & -2405 & -591 & -1006 & -133 & 2289 \\
\cline { 2 - 7 } & Maximum & 7747 & 7189 & 19849 & 36615 & 34550 \\
\hline \multirow{5}{*}{ Leverage } & Mean & 1.241 & 1.175 & 2.336 & 1.338 & 0.874 \\
\cline { 2 - 7 } & Std Dev & 1.608 & 1.161 & 5.591 & 1.558 & 0.705 \\
\cline { 2 - 7 } & Minimum & -6.919 & -1.856 & -2.998 & -5.972 & 0.015 \\
\cline { 2 - 7 } & Maximum & 4.949 & 4.251 & 50.266 & 10.593 & 3.831 \\
\hline
\end{tabular}


Table 2.4 Coefficient estimates from regressions of Tobin's $Q$ on the management style variables using OLS.

t-statistics are in parentheses and asterisks denote significance levels: * indicates significance at the $10 \%$ level, $* *$ at the $5 \%$ level, and $* * *$ at $1 \%$ level.

\begin{tabular}{|l|l|l|}
\hline VARIABLE & TOBIN'S Q & TOBIN'S Q \\
\hline Intercept & -0.371 & -0.742 \\
& $(-0.74)$ & $(-1.46)$ \\
\hline Size & $0.076 * *$ & $0.080 * *$ \\
& $(2.22)$ & $(2.34)$ \\
\hline Crony & $-0.168 * *$ & \\
& $(-2.09)$ & \\
\hline Family & & $0.191 *$ \\
& & $(1.79)$ \\
Corp & & $0.309 * * *$ \\
& & $(2.75)$ \\
\hline Leverage & $-0.024 *$ & $-0.024 * *$ \\
& $(-1.91)$ & $(-1.99)$ \\
\hline Commerce & 0.043 & 0.042 \\
& $(0.30)$ & $(0.29)$ \\
\hline Service & $0.456 * * *$ & $0.458 * * *$ \\
& $(3.50)$ & $(3.52)$ \\
\hline Construction & -0.059 & -0.053 \\
& $(-0.50)$ & $(-0.45)$ \\
\hline Manu & 0.027 & 0.041 \\
& $(0.24)$ & $(0.36)$ \\
\hline \#Obs & 315 & 315 \\
\hline Adjusted & 0.093 & 0.099 \\
R_square & & \\
\hline
\end{tabular}


Table 2.5 Coefficient estimates from regressions of performances on the Tobin's $Q$ variables using OLS.

t-statistics are in parentheses and asterisks denote significance levels: * indicates significance at the $10 \%$ level, $* *$ at the $5 \%$ level, and $* * *$ at $1 \%$ level.

\begin{tabular}{|l|l|l|l|l|}
\hline VARIABLE & $\begin{array}{l}\text { GROSS } \\
\text { MARGIN }\end{array}$ & ROA & ROE & $\begin{array}{l}\text { EXCESS } \\
\text { STOCK } \\
\text { RETURN }\end{array}$ \\
\hline Intercept & $0.610 * * *$ & $-0.608 * * *$ & -0.492 & -19.924 \\
& $(4.33)$ & $(-4.20)$ & $(-0.82)$ & $(-0.34)$ \\
\hline Size & $-0.030 * * *$ & $0.042 * * *$ & 0.040 & 1.523 \\
& $(-3.17)$ & $(4.21)$ & $(0.97)$ & $(0.37)$ \\
\hline Commerce & $0.082 *$ & -0.024 & -0.006 & -13.457 \\
& $(1.96)$ & $(-0.57)$ & $(-0.04)$ & $(-0.77)$ \\
\hline Service & $0.234 * * *$ & 0.012 & -0.097 & -11.797 \\
& $(6.24)$ & $(0.32)$ & $(-0.61)$ & $(-0.75)$ \\
\hline Construction & $0.129 * * *$ & -0.047 & $-0.294 * *$ & -22.279 \\
& $(3.89)$ & $(-1.39)$ & $(-2.07)$ & $(-1.60)$ \\
\hline Manu & 0.046 & 0.014 & -0.105 & 0.079 \\
& $(1.42)$ & $(0.44)$ & $(-0.76)$ & $(0.01)$ \\
\hline Tobin's q & $0.055 * * *$ & $0.040 * *$ & 0.072 & $43.196 * * *$ \\
& $(3.46)$ & $(2.49)$ & $(1.07)$ & $(6.49)$ \\
\hline \#Obs & 315 & 315 & 315 & 315 \\
\hline Adjusted & 0.198 & 0.085 & 0.008 & 0.127 \\
R_square & & & & \\
\hline
\end{tabular}


Table 2.6 Coefficient estimates from regressions of Tobin's $q$ on the family director variables and Tobin's q on performance variables using 2 SLS.

t-statistics are in the parentheses and asterisks denote significance levels: * indicates significance at the $10 \%$ level, $* *$ at the $5 \%$ level, and $* * *$ at $1 \%$ level.

System of equations on Family and corporation

\begin{tabular}{|c|c|c|c|c|c|}
\hline VARIABLE & TOBIN'S Q & $\begin{array}{l}\text { GROSS } \\
\text { MARGIN }\end{array}$ & ROA & ROE & $\begin{array}{l}\text { EXCESS } \\
\text { STOCK } \\
\text { RETURN }\end{array}$ \\
\hline Intercept & $\begin{array}{l}-0.742 \\
(-1.46) \\
\end{array}$ & $\begin{array}{l}0.604 * * * \\
(4.10)\end{array}$ & $\begin{array}{l}-0.638 * * * \\
(-4.11) \\
\end{array}$ & $\begin{array}{l}-0.075 \\
(-0.05)\end{array}$ & $\begin{array}{l}-30.817 \\
(-0.51)\end{array}$ \\
\hline Size & $\begin{array}{l}0.080 * * \\
(2.34)\end{array}$ & $\begin{array}{l}-0.035 * * * \\
(-3.14)\end{array}$ & $\begin{array}{l}0.049 * * * \\
(4.15)\end{array}$ & $\begin{array}{l}-0.144 \\
(-1.19)\end{array}$ & $\begin{array}{l}0.442 \\
(0.10)\end{array}$ \\
\hline $\begin{array}{l}\text { Family } \\
\text { Corp }\end{array}$ & $\begin{array}{l}0.191 * \\
(1.79) \\
0.309 * * * \\
(2.75) \\
\end{array}$ & & & & \\
\hline Leverage & $\begin{array}{l}-0.024 * * \\
(-1.99)\end{array}$ & & & & \\
\hline Commerce & $\begin{array}{l}0.042 \\
(0.29)\end{array}$ & $\begin{array}{l}0.108 * * \\
(2.36)\end{array}$ & $\begin{array}{l}-0.034 \\
(-0.72)\end{array}$ & $\begin{array}{l}0.502 \\
(1.03)\end{array}$ & $\begin{array}{l}-0.192 \\
(-0.01)\end{array}$ \\
\hline Service & $\begin{array}{l}0.458 * * * \\
(3.52)\end{array}$ & $\begin{array}{l}0.255 * * * \\
(6.63)\end{array}$ & \begin{tabular}{|l|}
0.036 \\
$(0.89)$
\end{tabular} & $\begin{array}{l}-0.201 \\
(-0.49)\end{array}$ & $\begin{array}{l}6.633 \\
(0.42)\end{array}$ \\
\hline Construction & $\begin{array}{l}-0.053 \\
(-0.45)\end{array}$ & $\begin{array}{l}0.165 * * * \\
(3.96)\end{array}$ & $\begin{array}{l}-0.070 \\
(-1.61)\end{array}$ & $\begin{array}{l}0.545 \\
(1.23)\end{array}$ & $\begin{array}{l}-6.452 \\
(-0.38)\end{array}$ \\
\hline Manu & $\begin{array}{l}0.041 \\
(0.36)\end{array}$ & $\begin{array}{l}0.073 * * \\
(1.98)\end{array}$ & $\begin{array}{l}0.0102 \\
(0.06)\end{array}$ & $\begin{array}{l}0.464 \\
(1.17)\end{array}$ & $\begin{array}{l}13.820 \\
(0.91)\end{array}$ \\
\hline Tobin's q & & $\begin{array}{l}0.134 * \\
(1.71)\end{array}$ & $\begin{array}{l}-0.068 \\
(-0.83)\end{array}$ & $\begin{array}{l}2.883 * * * \\
(3.45)\end{array}$ & $\begin{array}{l}\text { 64.676*** } \\
(2.01)\end{array}$ \\
\hline $\begin{array}{l}\text { Adjusted } \\
\text { R_square }\end{array}$ & 0.099 & 0.167 & 0.059 & 0.021 & 0.023 \\
\hline $\begin{array}{l}\text { Wu-Hausman } \\
\text { Test for } \\
\text { endogeneity of } \\
\text { Q }\end{array}$ & & $\begin{array}{l}1.32 \\
(0.2513)\end{array}$ & \begin{tabular}{|l|}
1.79 \\
$(0.1814)$
\end{tabular} & $\begin{array}{l}121.32 * * * \\
(0.0001)\end{array}$ & $\begin{array}{l}0.70 \\
(0.4020)\end{array}$ \\
\hline $\begin{array}{l}\text { Overidentifying } \\
\text { Restrictions } \\
\text { test }\end{array}$ & & $\begin{array}{l}0.345 \\
\text { Fail to reject } \\
\mathrm{H}_{\mathrm{o}}\end{array}$ & \begin{tabular}{|l}
0.284 \\
Fail to \\
reject $\mathrm{H}_{\mathrm{o}}$
\end{tabular} & $\begin{array}{l}6.933 \\
\text { Reject } \mathrm{H}_{\mathrm{o}} \text { at } \\
1 \%\end{array}$ & $\begin{array}{l}0.032 \\
\text { Fail to reject } \\
\mathrm{H}_{\mathrm{o}}\end{array}$ \\
\hline
\end{tabular}


Table 3.1: Mean and Variance of Returns by Three Different Styles of Management

\begin{tabular}{|c|c|c|}
\hline Style of management & Mean return & Variance \\
\hline Corporation & 82.20 & 20252.84 \\
\hline Family & 80.93 & 28205.84 \\
\hline Partner & 67.43 & 4766.70 \\
\hline
\end{tabular}

Table 3.2: Descriptive Statistics Comparison of Unleverage Beta from Three Different Styles of Management Use Excess Return Calculated from Index the Stock Exchange of Thailand and World Market Index as Market Return.

\begin{tabular}{|c|c|c|c|c|c|c|}
\hline \multirow{2}{*}{$\begin{array}{c}\text { Descriptive } \\
\text { Statistics }\end{array}$} & \multicolumn{3}{|c|}{ Thai Market return } & \multicolumn{3}{c|}{ World Market Return } \\
\cline { 2 - 7 } & $\begin{array}{c}\text { U_Beta_T } \\
\text { Corporation }\end{array}$ & $\begin{array}{c}\text { U_Beta_T } \\
\text { Family }\end{array}$ & $\begin{array}{c}\text { U_Beta_T } \\
\text { Partnership }\end{array}$ & $\begin{array}{c}\text { U_Beta_W } \\
\text { Corporation }\end{array}$ & $\begin{array}{c}\text { U_Beta_W } \\
\text { Family }\end{array}$ & $\begin{array}{c}\text { U_Beta_W } \\
\text { Partnership }\end{array}$ \\
\hline Mean & -0.09 & -0.12 & 0.24 & 0.973 & 1.317 & -0.943 \\
\hline S.D. & 7.61 & 1.95 & 3.57 & 19.75 & 14.40 & 25.06 \\
\hline Maximum & 24.28 & 11.42 & 17.48 & 181.45 & 73.61 & 91.21 \\
\hline Minimum & -71.53 & -9.67 & -12.88 & -44.69 & -64.63 & -126.90 \\
\hline
\end{tabular}

Table 3.3: Abnormal Returns from Three Different Styles of Management Using CAPM with Thai Market Return and World Market Return.

\begin{tabular}{|c|c|c|c|c|c|c|}
\hline \multirow{2}{*}{$\begin{array}{c}\text { Descriptive } \\
\text { Statistics }\end{array}$} & \multicolumn{3}{|c|}{ Use Thai Market return } & \multicolumn{3}{c|}{ Use World Market Return } \\
\cline { 2 - 7 } & $\begin{array}{c}\text { Alpha_T } \\
\text { Corporation }\end{array}$ & $\begin{array}{c}\text { Alpha_T } \\
\text { Family }\end{array}$ & $\begin{array}{c}\text { Alpha_T } \\
\text { Partnership }\end{array}$ & $\begin{array}{c}\text { Alpha_W } \\
\text { Corporation }\end{array}$ & $\begin{array}{c}\text { Alpha_W } \\
\text { Family }\end{array}$ & $\begin{array}{c}\text { Alpha_W } \\
\text { Partnership }\end{array}$ \\
\hline Mean & 77.39 & 75.17 & 46.87 & 81.97 & 88.72 & 56.37 \\
\hline S.D. & 140.74 & 169.53 & 85.11 & 140.30 & 191.28 & 92.84 \\
\hline Maximum & 784.49 & 1394.25 & 507.20 & 866.77 & 1550.65 & 558.34 \\
\hline Minimum & -62.20 & -43.71 & -13.62 & -58.40 & -24.71 & -9.59 \\
\hline
\end{tabular}


Table 3.4 Three-factor Fama and French Regressions that Use Book-to-Market, Size Small-Big Returns, Value-Growth Returns, and Monthly Excess Returns on the Thai Market Portfolio and U.S. Market Portfolio to Explain Monthly Excess Returns on Three Different Styles of Management

\begin{tabular}{|c|c|c|c|c|c|c|}
\hline \multirow[b]{2}{*}{$\begin{array}{c}\text { Descriptive } \\
\text { Statistics }\end{array}$} & \multicolumn{3}{|c|}{ Use Thai Market return } & \multicolumn{3}{|c|}{ Use U.S. Market Return } \\
\hline & $\begin{array}{c}\alpha \_ \text {FF_T } \\
\text { Corporation }\end{array}$ & $\begin{array}{c}\alpha \_ \text {FF_T } \\
\text { Family }\end{array}$ & $\begin{array}{c}\alpha \_ \text {FF_T } \\
\text { Partnership }\end{array}$ & $\begin{array}{c}\alpha \_ \text {FF_W } \\
\text { Corporation }\end{array}$ & $\begin{array}{c}\alpha \_\mathrm{FF} W \mathrm{~W} \\
\text { Family }\end{array}$ & $\begin{array}{c}\alpha \_ \text {FF_W } \\
\text { Partnership }\end{array}$ \\
\hline Mean & 24.76 & 10.80 & -11.58 & 11.15 & 11.40 & -3.06 \\
\hline S.D. & 227.26 & 192.15 & 133.26 & 86.10 & 101.21 & 54.17 \\
\hline Maximum & 1551.85 & 1245.81 & 675.12 & 630.69 & 785.45 & 208.93 \\
\hline Minimum & -342.66 & -507.40 & -173.56 & -85.52 & -122.58 & -75.24 \\
\hline
\end{tabular}

\begin{tabular}{|c|c|c|c|c|c|c|}
\hline \multirow{2}{*}{$\begin{array}{c}\text { Descriptive } \\
\text { Statistics }\end{array}$} & \multicolumn{3}{|c|}{ Use Thai Market return } & \multicolumn{3}{c|}{ Use U.S. Market Return } \\
\cline { 2 - 7 } & $\begin{array}{c}\beta_{\text {im__FF_T }} \text { Corporation } \\
\text { Mean }\end{array}$ & $\begin{array}{c}\beta_{\text {im__FF_T }} \\
\text { Family }\end{array}$ & $\begin{array}{c}\beta_{\text {im_FF_T }} \\
\text { Partnership }\end{array}$ & $\begin{array}{c}\beta_{\text {im__F__W }} \\
\text { Corporation }\end{array}$ & $\begin{array}{c}\beta_{\text {im__FF_W }} \\
\text { Family }\end{array}$ & $\begin{array}{c}\beta_{\text {iim_FF_W }} \\
\text { Partnership }\end{array}$ \\
\hline S.D. & -0.06 & -1.06 & -2.27 & 18.84 & 7.61 & 13.04 \\
\hline Maximum & 13.83 & 12.72 & 9.56 & 44.33 & 48.68 & 26.56 \\
\hline Minimum & -26.79 & 80.43 & 47.06 & 224.96 & 202.75 & 114.25 \\
\hline
\end{tabular}

\begin{tabular}{|c|c|c|c|c|c|c|}
\hline \multirow[b]{2}{*}{$\begin{array}{c}\text { Descriptive } \\
\text { Statistics }\end{array}$} & \multicolumn{3}{|c|}{ Use Thai Market return } & \multicolumn{3}{|c|}{ Use U.S. Market Return } \\
\hline & $\begin{array}{c}\beta_{\text {is__FF_T }} \mathrm{FF}_{-} \\
\text {Corporation }\end{array}$ & $\begin{array}{c}\beta_{\text {is__FF_T }} \text { FF_mily }^{2} \\
\text { Fam }\end{array}$ & $\begin{array}{c}\beta_{\text {is_FF_T }} F_{-} \\
\text {Partnership }\end{array}$ & $\begin{array}{c}\beta_{\text {is_FF_W }} \text { FF_- } \\
\text { Corporation }\end{array}$ & $\begin{array}{c}\beta_{\text {is_FF_W }} \text { FF } \\
\text { Family }\end{array}$ & $\begin{array}{c}\beta_{\text {is_FF_W }} \text { FF } \\
\text { Partnership }\end{array}$ \\
\hline Mean & -0.01 & 0.14 & -0.37 & 102.87 & 119.55 & 103.91 \\
\hline S.D. & 5.71 & 4.40 & 3.67 & 234.45 & 302.40 & 137.27 \\
\hline Maximum & 25.01 & 44.76 & 16.71 & 1477.86 & 2583.25 & 541.70 \\
\hline Minimum & -47.27 & -12.22 & -15.78 & -51.83 & -44.36 & -88.88 \\
\hline
\end{tabular}

\begin{tabular}{|c|c|c|c|c|c|c|}
\hline \multirow[b]{2}{*}{$\begin{array}{c}\text { Descriptive } \\
\text { Statistics }\end{array}$} & \multicolumn{3}{|c|}{ Use Thai Market return } & \multicolumn{3}{|c|}{ Use U.S. Market Return } \\
\hline & $\begin{array}{c}\beta_{\mathrm{iv} \_} \mathrm{FF}{ }_{-T}^{\mathrm{T}} \\
\text { Corporation }\end{array}$ & $\begin{array}{c}\beta_{\text {iv_ }} \text { FF_T } \\
\text { Family }\end{array}$ & $\begin{array}{c}\beta_{\mathrm{iv}_{-}} \mathrm{FF}_{-} \mathrm{T} \\
\text { Partnership }\end{array}$ & $\begin{array}{c}\beta_{\mathrm{iv}_{-}} \mathrm{FF} \mathrm{F}_{-} \mathrm{W} \\
\text { Corporation }\end{array}$ & 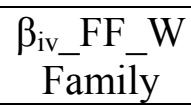 & $\begin{array}{c}\beta_{\mathrm{iv}_{-}} \mathrm{FF}{ }_{-} \mathrm{W} \\
\text { Partnership }\end{array}$ \\
\hline Mean & 1.02 & 1.24 & 1.07 & 81.12 & 90.31 & 80.47 \\
\hline S.D. & 2.40 & 2.50 & 1.65 & 179.46 & 237.92 & 110.96 \\
\hline Maximum & 18.78 & 18.74 & 7.88 & 1102.09 & 1926.85 & 409.69 \\
\hline Minimum & -4.69 & -0.77 & -0.64 & -100.75 & -1193.62 & -115.15 \\
\hline
\end{tabular}


Table 4.1: Descriptive variables use in the Binomial and Bivariate Probit.

\begin{tabular}{|l|r|r|r|r|r|}
\hline Variables & Mean & Std.Dev. & Minimum & Maximum & NumCases \\
\hline BANKRUPT & 0.279 & 0.449 & 0 & 1 & 315 \\
\hline LIQUIDATION & 0.133 & 0.340 & 0 & 1 & 315 \\
\hline FAMILYD & 0.473 & 0.500 & 0 & 1 & 315 \\
\hline PARTNER & 0.171 & 0.377 & 0 & 1 & 315 \\
\hline SIZEA & 14.067 & 1.116 & 10.113 & 17.932 & 315 \\
\hline LEVERAGE & 1.482 & 3.101 & -6.919 & 50.266 & 315 \\
\hline COMMERCE & 0.104 & 0.306 & 0 & 1 & 315 \\
\hline AGRICULT & 0.177 & 0.382 & 0 & 1 & 315 \\
\hline CONSTRUC & 0.260 & 0.439 & 0 & 1 & 315 \\
\hline MANU & 0.288 & 0.453 & 0 & 1 & 315 \\
\hline BankDirF & 0.158 & 0.165 & 0 & 0.769 & 315 \\
\hline FBankDirF & 0.104 & 0.144 & 0 & 0.750 & 315 \\
\hline TOBIN_Q & 0.629 & 0.708 & 0.029 & 5.319 & 315 \\
\hline DBankdir & 0.695 & 0.461 & 0 & 1 & 315 \\
\hline DFBankDir & 0.501 & 0.500 & 0 & 1 & 315 \\
\hline BAD96 & 0.041 & 0.199 & 0 & 1 & 315 \\
\hline BANKFAM & 0.065 & 0.126 & 0 & 0.714 & 315 \\
\hline BANKPART & 0.039 & 0.117 & 0 & 0.769 & 315 \\
\hline
\end{tabular}


Table 4.2: Binomial Probit Regression Results

\begin{tabular}{|c|c|c|c|c|}
\hline Dependent Variable & \multicolumn{2}{|c|}{ BANKRUPT } & \multicolumn{2}{|c|}{ LIQUIDATION } \\
\hline Constant & $\begin{array}{r}1.269 \\
(1.059)\end{array}$ & $\begin{array}{r}1.293 \\
(1.061)\end{array}$ & $\begin{array}{c}-2.089^{* * *} \\
(0.379)\end{array}$ & $\begin{array}{r}-1.742^{* * *} \\
(0.385)\end{array}$ \\
\hline PARTNER & $\begin{array}{c}-0.558^{* *} \\
(0.239) \\
\end{array}$ & $\begin{array}{c}-0.558^{* *} \\
(0.238) \\
\end{array}$ & $\begin{array}{r}-0.527 \\
(0.517) \\
\end{array}$ & $\begin{array}{r}-0.450 \\
(0.498) \\
\end{array}$ \\
\hline FAMILYD & $\begin{array}{r}-0.629^{* * *} \\
(0.178) \\
\end{array}$ & $\begin{array}{c}-0.624^{* * *} \\
(0.076)\end{array}$ & $\begin{array}{r}0.210 \\
(0.301) \\
\end{array}$ & $\begin{array}{r}-0.103 \\
(0.262) \\
\end{array}$ \\
\hline COMMERCE & $\begin{array}{r}0.434 \\
(0.335) \\
\end{array}$ & $\begin{array}{r}0.423 \\
(0.337) \\
\end{array}$ & $\begin{array}{r}0.211 \\
(0.491) \\
\end{array}$ & $\begin{array}{r}0.258 \\
(0.471) \\
\end{array}$ \\
\hline AGRICULT & $\begin{array}{l}0.633^{* *} \\
(0.296)\end{array}$ & $\begin{array}{l}0.617^{* *} \\
(0.302)\end{array}$ & $\begin{array}{l}0.951^{* *} \\
(0.379)\end{array}$ & $\begin{array}{l}0.855^{* *} \\
(0.377) \\
\end{array}$ \\
\hline CONSTRUC & $\begin{array}{l}0.640^{* *} \\
(0.275) \\
\end{array}$ & $\begin{array}{l}0.633^{* *} \\
(0.275) \\
\end{array}$ & $\begin{array}{r}0.576 \\
(0.370) \\
\end{array}$ & $\begin{array}{r}0.580 \\
(0.363) \\
\end{array}$ \\
\hline MANU & $\begin{array}{c}0.468^{*} \\
(0.273)\end{array}$ & $\begin{array}{c}0.462^{*} \\
(0.273)\end{array}$ & $\begin{array}{r}0.600 \\
(0.374)\end{array}$ & $\begin{array}{r}0.524 \\
(0.363)\end{array}$ \\
\hline SIZEA & $\begin{array}{c}-0.146^{*} \\
(0.076)\end{array}$ & $\begin{array}{c}-0.146{ }^{*} \\
(0.076)\end{array}$ & & \\
\hline LEVERAGE & $\begin{array}{c}0.178^{* * *} \\
(0.056) \\
\end{array}$ & $\begin{array}{c}0.180^{* * *} \\
(0.056)\end{array}$ & & \\
\hline TOBIN_Q & $\begin{array}{c}-0.260^{*} \\
(0.156)\end{array}$ & $\begin{array}{l}-0.260^{*} \\
(0.155)\end{array}$ & & \\
\hline BankDirF & $\begin{array}{r}-0.096 \\
(0.658) \\
\end{array}$ & & $\begin{array}{r}1.466 \\
(1.056) \\
\end{array}$ & \\
\hline FBankDirF & $\begin{array}{r}0.158 \\
(0.758)\end{array}$ & & $\begin{array}{c}1.790^{*} \\
(0.926)\end{array}$ & \\
\hline DBankdir & & $\begin{array}{r}-0.088 \\
(0.205)\end{array}$ & & $\begin{array}{r}-0.220 \\
(0.288)\end{array}$ \\
\hline DFBankDir & & $\begin{array}{r}0.084 \\
(0.187) \\
\end{array}$ & & $\begin{array}{l}0.569^{* *} \\
(0.253) \\
\end{array}$ \\
\hline BANKFAM & & & $\begin{array}{r}-2.667^{* *} \\
(1.319) \\
\end{array}$ & $\begin{array}{r}-0.769 \\
(1.119) \\
\end{array}$ \\
\hline BANKPART & & & $\begin{array}{l}-4.364^{*} \\
(2.359)\end{array}$ & $\begin{array}{r}-1.964 \\
(2.28)\end{array}$ \\
\hline BAD96 & & & $\begin{array}{r}2.269^{* * *} \\
(0.449)\end{array}$ & $\begin{array}{c}2.245^{* * *} \\
(0.458)\end{array}$ \\
\hline Observations & 315 & 315 & 315 & 315 \\
\hline
\end{tabular}

Standard Errors are in parentheses.

Asterisks denote significance levels: * 10\% level, ** 5\% level, and *** 1\% level. 
Table 4.3 Bivariate Probit Regression Results

\begin{tabular}{|c|c|c|c|c|}
\hline Dependent Variable & \multicolumn{2}{|c|}{ BANKRUPT } & \multicolumn{2}{|c|}{ LIQUIDATION } \\
\hline Constant & $\begin{array}{r}1.147 \\
(1.179\end{array}$ & $\begin{array}{r}1.184 \\
(1.144)\end{array}$ & $\begin{array}{r}-1.573 \\
(1.092)\end{array}$ & $\begin{array}{r}-1.187 \\
(1.200)\end{array}$ \\
\hline PARTNER & $\begin{array}{c}-0.557^{* *} \\
(0.264)\end{array}$ & $\begin{array}{c}-0.556^{* *} \\
(0.271)\end{array}$ & $\begin{array}{r}-0.149 \\
(0.762)\end{array}$ & $\begin{array}{r}-0.689 \\
(0.661)\end{array}$ \\
\hline FAMILYD & $\begin{array}{r}-0.624^{* * *} \\
(0.187)\end{array}$ & $\begin{array}{r}-0.620^{* * *} \\
(0.187)\end{array}$ & $\begin{array}{r}0.677 \\
(0.673)\end{array}$ & $\begin{array}{r}0.257 \\
(0.557)\end{array}$ \\
\hline COMMERCE & $\begin{array}{r}0.425 \\
(0.343)\end{array}$ & $\begin{array}{r}0.412 \\
(0.358)\end{array}$ & $\begin{array}{c}-0.138 \\
(1.035)\end{array}$ & $\begin{array}{r}0.064 \\
(0.898)\end{array}$ \\
\hline AGRICULT & $\begin{array}{l}0.621^{* *} \\
(0.311)\end{array}$ & $\begin{array}{c}0.603^{*} \\
(0.320)\end{array}$ & $\begin{array}{r}1.135 \\
(0.770)\end{array}$ & $\begin{array}{r}0.948 \\
(0.794)\end{array}$ \\
\hline CONSTRUC & $\begin{array}{l}0.632^{* *} \\
(0.283)\end{array}$ & $\begin{array}{l}0.625^{* *} \\
(0.285)\end{array}$ & $\begin{array}{r}0.197 \\
(\mathbf{0 . 8 8 3})\end{array}$ & $\begin{array}{r}0.257 \\
(\mathbf{0 . 8 7 6})\end{array}$ \\
\hline MANU & $\begin{array}{r}0.462 \\
(0.282)\end{array}$ & $\begin{array}{r}0.457 \\
(0.283)\end{array}$ & $\begin{array}{r}0.275 \\
(0.775)\end{array}$ & $\begin{array}{r}0.280 \\
(0.758)\end{array}$ \\
\hline SIZEA & $\begin{array}{r}-0.137 \\
(0.084)\end{array}$ & $\begin{array}{c}-0.137^{*} \\
(0.083)\end{array}$ & & \\
\hline LEVERAGE & $\begin{array}{c}0.180^{* * *} \\
(0.045)\end{array}$ & $\begin{array}{c}0.181^{* * *} \\
(0.044)\end{array}$ & & \\
\hline TOBIN_Q & $\begin{array}{c}-0.273^{*} \\
(0.159)\end{array}$ & $\begin{array}{c}-0.276^{*} \\
(0.158)\end{array}$ & & \\
\hline BAD96 & & & $\begin{array}{c}1.363^{* * *} \\
(0.496)\end{array}$ & $\begin{array}{l}1.291^{* *} \\
(0.546)\end{array}$ \\
\hline BankDirF & $\begin{array}{r}-0.121 \\
(0.784)\end{array}$ & & $\begin{array}{r}1.654 \\
(2.628)\end{array}$ & \\
\hline FbankDirF & $\begin{array}{r}0.165 \\
(0.950)\end{array}$ & & $\begin{array}{r}3.226 \\
(2.265)\end{array}$ & \\
\hline Dbankdir & & $\begin{array}{r}-0.094 \\
(0.231) \\
\end{array}$ & & $\begin{array}{r}-0.229 \\
(0.466) \\
\end{array}$ \\
\hline DFBankDir & & $\begin{array}{r}0.083 \\
(0.204)\end{array}$ & & $\begin{array}{l}0.797^{* *} \\
(\mathbf{0 . 3 7 5 )}\end{array}$ \\
\hline BANKFAM & & & $\begin{array}{r}-3.801 \\
(2.678)\end{array}$ & $\begin{array}{r}-1.170 \\
(1.613)\end{array}$ \\
\hline BANKPART & & & $\begin{array}{r}-4.802 \\
(4.992)\end{array}$ & $\begin{array}{r}-1.858 \\
(3.677)\end{array}$ \\
\hline Rho & $\begin{array}{r}0.451 \\
(0.735)\end{array}$ & $\begin{array}{r}0.448 \\
(0.696)\end{array}$ & & \\
\hline Observations & 315 & 315 & 88 & 88 \\
\hline
\end{tabular}

Standard Errors are in parentheses.

Asterisks denote significance levels: * 10\% level, ** 5\% level, and *** 1\% level. 


\section{Appendix I: Law of person's identification}

This dissertation has used the last name to identify family businesses because Thai law allows only family members to use the same last name. In order to have better understanding, I have summarized Wiroon Yamlami’s dissertation (1991) “Law of person's identification"

Up to about 90 years ago, people in Thailand did not use last names. To identify a person, we normally added their occupation to the name. Though the Thai and Chinese have had long relationships and adapted many cultures, Chinese last names had never applied to Thais. Thailand also had relationships with other countries in Europe. We adopted civillaws from the French, but only a few upper class families used a last name. King Rama VI realized this problem of identification with the growing society. His philosophy was to use the last name as an identification of the family in which a person was born. To accomplish that everybody had to adopt a last name.

The laws of last names came into force in 1913. The legal procedures begin with the last name and have to be different from the first name. The last name has to be registered and approved by the government. The registered last name of a family cannot be used by members of other families. The most important issue here is that two people who have the same last name must be born from the same father. A female and her offspring were allowed to use her husband's last name. Later on in 1962, it was decided that a female must use her husband's last name. At the beginning, King Rama VI gave last names to many families who asked for them. There are a few ways to use a particular last name. Firstly, the last name is applied for the newborn baby in the family. Secondly, an adopted baby is legally allowed to use the same last name as her adopted family. 
The benefit from using the last name is mainly for a person to be connected to his father with pride and dignity. Fame and fortune in family will pass on to the next generation through the last name. The family member will then be responsible to keep the last name from the notoriety. Besides, it helps create a bond among family members. 


\section{Appendix II: Regressions that use Herfindahl-Hirschman index (HHI)}

Table 2.4A Coefficient estimates from regressions of Tobin's $Q$ on the management style variables using OLS.

t-statistics are in parentheses and asterisks denote significance levels: * indicates significance at the $10 \%$ level, $* *$ at the $5 \%$ level, and $* * *$ at $1 \%$ level.

\begin{tabular}{|l|l|l|l|}
\hline VARIABLE & TOBIN'S Q & TOBIN'S Q & TOBIN'S Q \\
\hline Intercept & $\begin{array}{l}-0.582 \\
(-1.12)\end{array}$ & $\begin{array}{l}-0.588 \\
(-1.12)\end{array}$ & $\begin{array}{l}-0.504 \\
(-0.99)\end{array}$ \\
\hline Size & $\begin{array}{l}0.079 * * \\
(2.27)\end{array}$ & $\begin{array}{l}0.080 * * \\
(2.29)\end{array}$ & $\begin{array}{l}0.077 * * \\
(2.23)\end{array}$ \\
\hline HHI & 0.000 & & \\
& $(0.54)$ & & \\
\hline HHIA & & 0.044 & \\
& & $(0.51)$ & \\
\hline HHIB & & & -0.022 \\
& & & $(-0.23)$ \\
\hline Leverage & $-0.025 *$ & $-0.025 * *$ & $-0.025 * *$ \\
& $(-2.01)$ & $(-2.03)$ & $(-2.04)$ \\
\hline Commerce & 0.052 & 0.048 & 0.045 \\
& $(0.35)$ & $(0.32)$ & $(0.30)$ \\
\hline Service & $0.509 * * *$ & $0.504 * * *$ & $0.490 * * *$ \\
& $(3.79)$ & $(3.79)$ & $(3.67)$ \\
\hline Construction & -0.032 & -0.033 & -0.037 \\
& $(-0.27)$ & $(-0.27)$ & $(-0.31)$ \\
\hline Manu & 0.047 & 0.044 & 0.031 \\
& $(0.39)$ & $(0.38)$ & $(0.27)$ \\
\hline \#Obs & 310 & 310 & 310 \\
\hline Adjusted & 0.080 & 0.080 & 0.079 \\
R_square & & & \\
\hline
\end{tabular}


Table 2.5A Coefficient estimates from regressions of performances on the HHI variables using OLS.

t-statistics are in parentheses and asterisks denote significance levels: * indicates significance at the $10 \%$ level, $* *$ at the $5 \%$ level, and $* * *$ at $1 \%$ level.

\begin{tabular}{|l|l|l|l|l|}
\hline VARIABLE & $\begin{array}{l}\text { GROSS } \\
\text { MARGIN }\end{array}$ & ROA & ROE & $\begin{array}{l}\text { EXCESS } \\
\text { STOCK } \\
\text { RETURN }\end{array}$ \\
\hline Intercept & $0.641 * * *$ & $-0.639 * * *$ & -0.630 & -86.790 \\
& $(4.28)$ & $(-4.23)$ & $(-1.01)$ & $(-1.34)$ \\
\hline Size & $-0.028 * * *$ & $0.045 * * *$ & 0.048 & 4.726 \\
& $(-2.83)$ & $(4.48)$ & $(1.15)$ & $(1.09)$ \\
\hline Commerce & $0.084 * *$ & -0.022 & 0.002 & -11.509 \\
& $(1.97)$ & $(-0.50)$ & $(0.01)$ & $(-0.61)$ \\
\hline Service & $0.253 * * *$ & 0.034 & -0.039 & 11.361 \\
& $(6.63)$ & $(0.89)$ & $(-0.25)$ & $(0.68)$ \\
\hline Construction & $0.129 * * *$ & -0.050 & $-0.295 * *$ & $-25.454 *$ \\
& $(3.81)$ & $(-1.43)$ & $(-2.04)$ & $(-1.70)$ \\
\hline Manu & 0.038 & 0.018 & -0.085 & 3.887 \\
& $(1.14)$ & $(0.53)$ & $(-0.59)$ & $(0.26)$ \\
\hline HHI & -0.000 & 0.000 & 0.000 & 0.004 \\
& $(-1.41)$ & $(0.25)$ & $(0.71)$ & $(0.66)$ \\
\hline \#Obs & 310 & 310 & 310 & 310 \\
\hline $\begin{array}{l}\text { Adjusted } \\
\text { R_square }\end{array}$ & 0.178 & 0.067 & 0.006 & 0.010 \\
\hline
\end{tabular}


Table 2.5B Coefficient estimates from regressions of performances on the HHIA variables using OLS.

t-statistics are in parentheses and asterisks denote significance levels: * indicates significance at the $10 \%$ level, $* *$ at the $5 \%$ level, and $* * *$ at $1 \%$ level.

\begin{tabular}{|l|l|l|l|l|}
\hline VARIABLE & $\begin{array}{l}\text { GROSS } \\
\text { MARGIN }\end{array}$ & ROA & ROE & $\begin{array}{l}\text { EXCESS } \\
\text { STOCK } \\
\text { RETURN }\end{array}$ \\
\hline Intercept & $0.643 * * *$ & $-0.681 * * *$ & -0.520 & -74.948 \\
& $(4.33)$ & $(-4.48)$ & $(-0.82)$ & $(-1.15)$ \\
\hline Size & $-0.029 * * *$ & $0.047 * * *$ & 0.045 & 4.459 \\
& $(-2.92)$ & $(4.62)$ & $(1.09)$ & $(1.02)$ \\
\hline Commerce & $0.086 * *$ & -0.022 & -0.004 & -12.129 \\
& $(2.03)$ & $(-0.50)$ & $(-0.02)$ & $(-0.64)$ \\
\hline Service & $0.256 * * *$ & 0.039 & -0.063 & 8.895 \\
& $(6.78)$ & $(1.03)$ & $(-0.40)$ & $(0.53)$ \\
\hline Construction & $0.130 * * *$ & -0.048 & $-0.303 * *$ & $-26.192 *$ \\
& $(3.83)$ & $(-1.39)$ & $(-2.09)$ & $(-1.75)$ \\
\hline Manu & 0.039 & 0.023 & -0.104 & 1.821 \\
& $(1.16)$ & $(0.68)$ & $(-0.73)$ & $(0.02)$ \\
\hline HHIA & -0.037 & 0.032 & 0.005 & -1.377 \\
& $(-1.52)$ & $(1.27)$ & $(-0.05)$ & $(-0.13)$ \\
\hline \#Obs & 310 & 310 & 310 & 310 \\
& & & & \\
\hline Adjusted & 0.179 & 0.071 & 0.005 & 0.008 \\
R_square & & & & \\
\hline
\end{tabular}


Table 2.5C Coefficient estimates from regressions of performances on the HHIB variables using OLS.

t-statistics are in parentheses and asterisks denote significance levels: * indicates significance at the $10 \%$ level, ** at the $5 \%$ level, and $* * *$ at $1 \%$ level.

\begin{tabular}{|l|l|l|l|l|}
\hline VARIABLE & $\begin{array}{l}\text { GROSS } \\
\text { MARGIN }\end{array}$ & ROA & ROE & $\begin{array}{l}\text { EXCESS } \\
\text { STOCK } \\
\text { RETURN }\end{array}$ \\
\hline Intercept & $0.591 * * *$ & $-0.621 * * *$ & -0.602 & -82.354 \\
& $(4.09)$ & $(-4.19)$ & $(-0.98)$ & $(-1.30)$ \\
\hline Size & $-0.027 * * *$ & $0.045 * * *$ & 0.048 & 4.704 \\
& $(-2.76)$ & $(4.44)$ & $(1.16)$ & $(1.08)$ \\
\hline Commerce & $0.085 * *$ & -0.024 & 0.009 & -11.094 \\
& $(1.99)$ & $(-0.55)$ & $(0.05)$ & $(-0.59)$ \\
\hline Service & $0.261 * * *$ & 0.029 & -0.036 & 11.049 \\
& $(6.86)$ & $(0.76)$ & $(-0.23)$ & $(0.66)$ \\
\hline Construction & $0.131 * * *$ & -0.052 & $-0.292 * *$ & $-25.365 *$ \\
& $(3.85)$ & $(-1.49)$ & $(-2.02)$ & $(-1.69)$ \\
\hline Manu & 0.045 & 0.014 & -0.0 .84 & 3.506 \\
& $(1.34)$ & $(0.41)$ & $(-0.59)$ & $(0.24)$ \\
\hline HHIB & -0.013 & -0.015 & 0.119 & 8.514 \\
& $(-0.49)$ & $(-0.56)$ & $(1.03)$ & $(0.71)$ \\
\hline \#Obs & 310 & 310 & 310 & 310 \\
& & & & \\
\hline Adjusted & 0.173 & 0.067 & 0.008 & 0.010 \\
R_square & & & & \\
\hline
\end{tabular}

